\title{
Miranda
}

Revue pluridisciplinaire du monde anglophone /

Multidisciplinary peer-reviewed journal on the English-

speaking world

13 | 2016

Thomas Spence and his Legacy: Bicentennial

Perspectives

\section{Say, display, replay: Erving Goffman meets Oscar Wilde}

Jean -Rémi Lapaire

\section{OpenEdition}

Journals

\section{Electronic version}

URL: http://journals.openedition.org/miranda/9505

DOI: $10.4000 /$ miranda.9505

ISSN: 2108-6559

\section{Publisher}

Université Toulouse - Jean Jaurès

Electronic reference

Jean -Rémi Lapaire, "Say, display, replay: Erving Goffman meets Oscar Wilde", Miranda [Online], 13

2016, Online since 24 November 2016, connection on 16 February 2021. URL: http://

journals.openedition.org/miranda/9505; DOI: https://doi.org/10.4000/miranda.9505

This text was automatically generated on 16 February 2021

\section{(c) (i) $\odot$}

Miranda is licensed under a Creative Commons Attribution-NonCommercial-NoDerivatives 4.0 International License. 


\title{
Say, display, replay: Erving Goffman meets Oscar Wilde
}

\author{
Jean -Rémi Lapaire
}

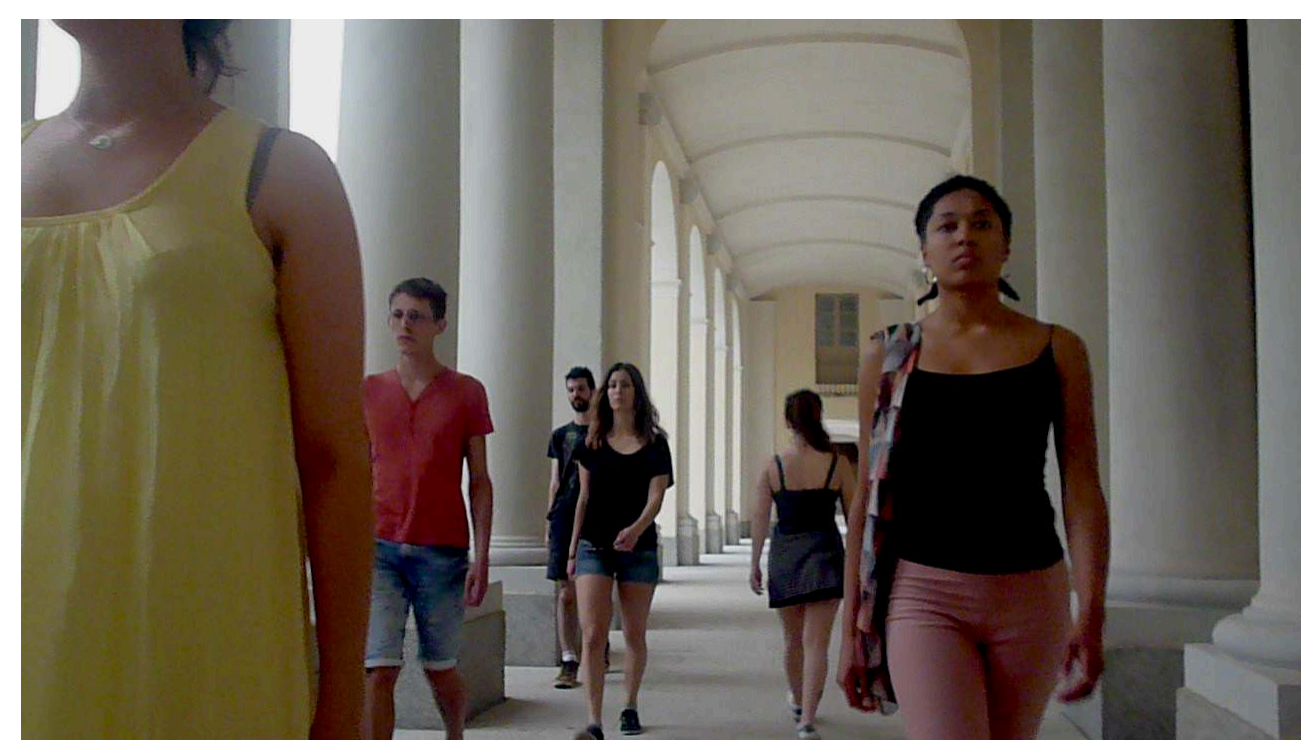

Script: Jean-Rémi Lapaire, Université Bordeaux Montaigne, France

Choreography: Jean Magnard ${ }^{1}$

Reader: Jean-Rémi Lapaire

4 Performers: Hugo Dabadie, Florian Escoubet, Julie Guede, Eleonora Martiian, Marie Nahon, Céline Salcho ${ }^{2}$ 




It is a fact of our human condition that, for most of us, our daily life is spent in the immediate presence of others; in other words, that whatever they are, our doings are likely to be, in the narrow sense, socially situated.

Erving Goffman (1982)

Other people are quite dreadful. The only possible society is oneself. Oscar Wilde (1895b)

\section{Foreword}

5 Pragmatics is the branch of linguistics that studies language in use-what speakers concretely do or avoid doing with words and utterances as they engage in communicative interaction. In this illustrated lecture-performance, speakers are taken for what they essentially are: social actors and moral movers (Birdwhistell 1970) who articulate meanings physically, using the rich semiotic resources of the human body, while attending to the face needs of fellow speakers (Goffman 1959, Brown \& Levinson 1986, Culpeper 2011).

6 The sounds and the movements that speakers produce are not only meaningful but patterned (Whorf 1956), since individual variation rarely strays from conventional formal arrangements (Langacker 2008): established sound patterns, movement patterns, intonation patterns, word patterns, and syntactic patterns, to which interactional patterns need to be added, since most social interaction has a strong ritual character (Goffman 1967, Schechner 2003).

7 The present piece was choreographed in May 2016 and performed on June 6, 2016 at the TILLIT festival (Teatro in Lingua, Lingua in Teatro), Università del Piemonte Orientale (UPO), Vercelli, Italy. The main speaker and the six performers were all involved in the "Language, Body and Mind" seminar during the Spring semester. The seminar promotes an active, experiential multimodal learning environment, integrating formal academic instruction, film screenings, annotation sessions and movement workshops. Special attention is paid to the observation and pragmatic interpretation of communicative behavioural events (Frey 1975) in film, and recorded conversations. Students are trained to look at how language is "orchestrated to a choreography of the 
human body" (Asher 1972), and how meanings- abstract or concrete- are not only produced but acted out on the socio-interactional stage. Participants in the workshop sessions are asked to re-enact and re-analyse some of the scenes or "little parades" (Goffman 1959) studied in class.

8 The lecture-performance was commissioned for the TILLIT 2016 festival, organized by Pr. Marco Pustianaz, Michaela Reinhardt and Umberto Capra (UPO). The script was written by Jean-Rémi Lapaire and the choreography designed by Jean Magnard. The visuals are either screenshots taken from the filmed performance at Teatro Barbieri (Vercelli, Italy) or "instant replays" shot outdoors shortly after the lectureperformance, in the beautiful historic district of Vercelli, near the Faculty of Literature and Philosophy (Università degli Studi del Piemonte Orientale).

\section{A note on the two protagonists and their fictive encounter}

9 Oscar Wilde died some 20 years before Erving Goffman was born. Yet, the two share a humorous understanding of "the art of impression management" (Goffman 1959). 

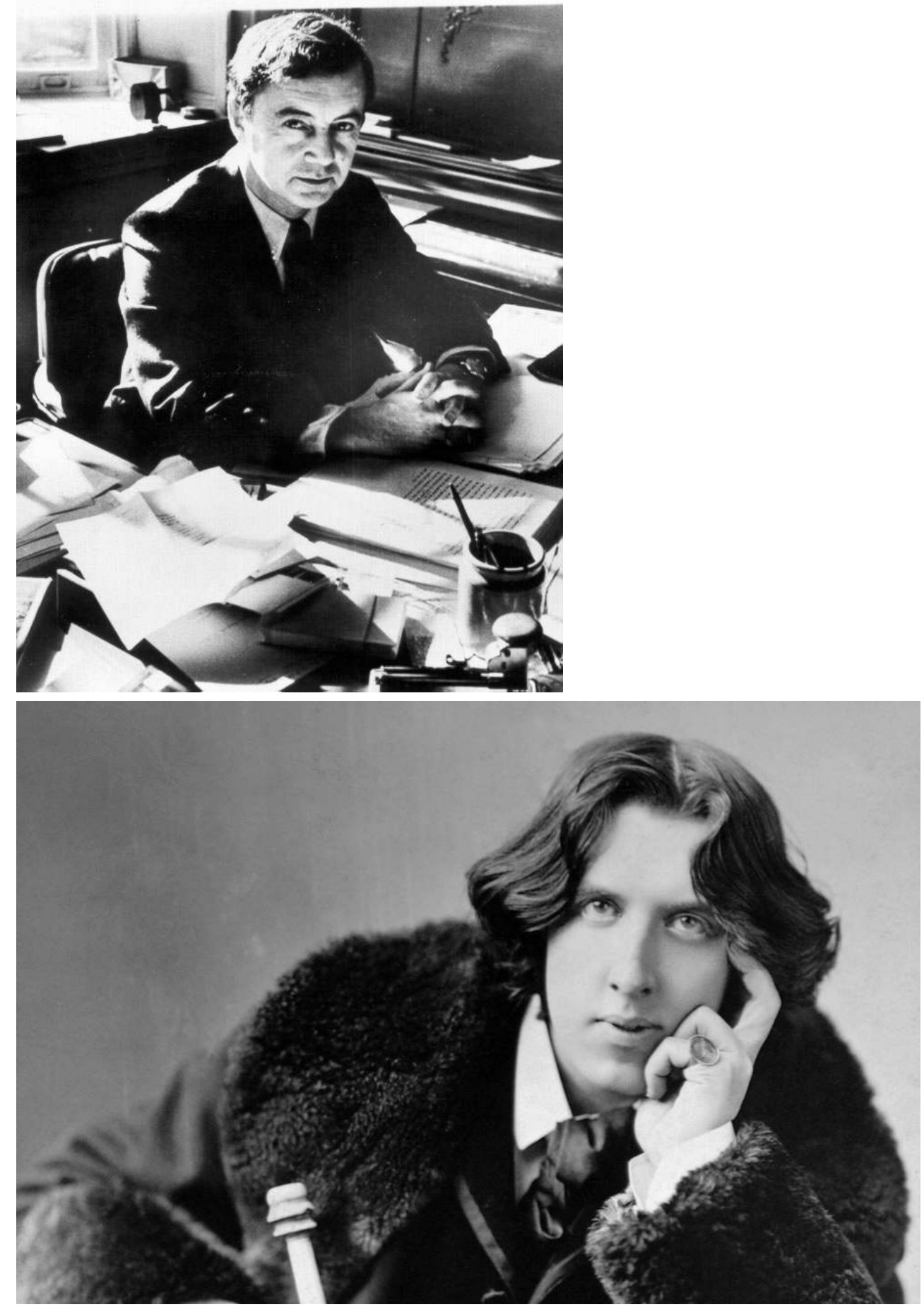

Erving Goffman (1922-1982), it will be recalled, was a Canadian-American sociologist and anthropologist. His dramaturgical model of speech was first introduced in The Presentation of Self in Everyday Life (1959) and later developed in Interactional Ritual (1967). Goffman's linguistic terminology borrowed extensively from the language of the theatrical performance: "setting", "décor", "performer", "actor", "interactants", "audience", “viewers", “parts", “roles", “lines", “scenes", “parades", “rituals", "performances", "dramatic realizations."

In his essays, Goffman paid particular attention to the "expressive order" and the "behavioral material" used when "persons come into one another's immediate 
presence" (Goffman 1967). He also set up a very useful distinction between expressions "given" (i.e. what social actors overtly say and display during their performances) and expressions "given off" (i.e. what is left for viewers and listeners to infer from the verbal and non verbal cues provided) during face-to-face interaction.

Goffman was also notorious for his study of "face", which he defined as "the positive social value a person claims for himself". "Maintaining face" and avoiding the "defacement of others" is part of "the interactional modus vivendi" that governs most "social encounters".

There is little need to introduce Oscar Wilde $(1854-1900)$ and his works. Two of his early plays, Lady Windermere's Fan (1893) and The Importance of Being Earnest (1895) provide precious humorous insight into the "ritual" quality of the "interaction order" (Goffman 1982) in London's upper "social circles". The mechanisms of "face-work" (Goffman 1967) are deconstructed, the calculated (and often witty) "information games" of interactants are revealed, while "concealment, discovery, and false revelations" (Goffman 1959) are exposed.

\section{Illustrated script of the performance at UPO, Vercelli, Italy (June 6, 2016)}
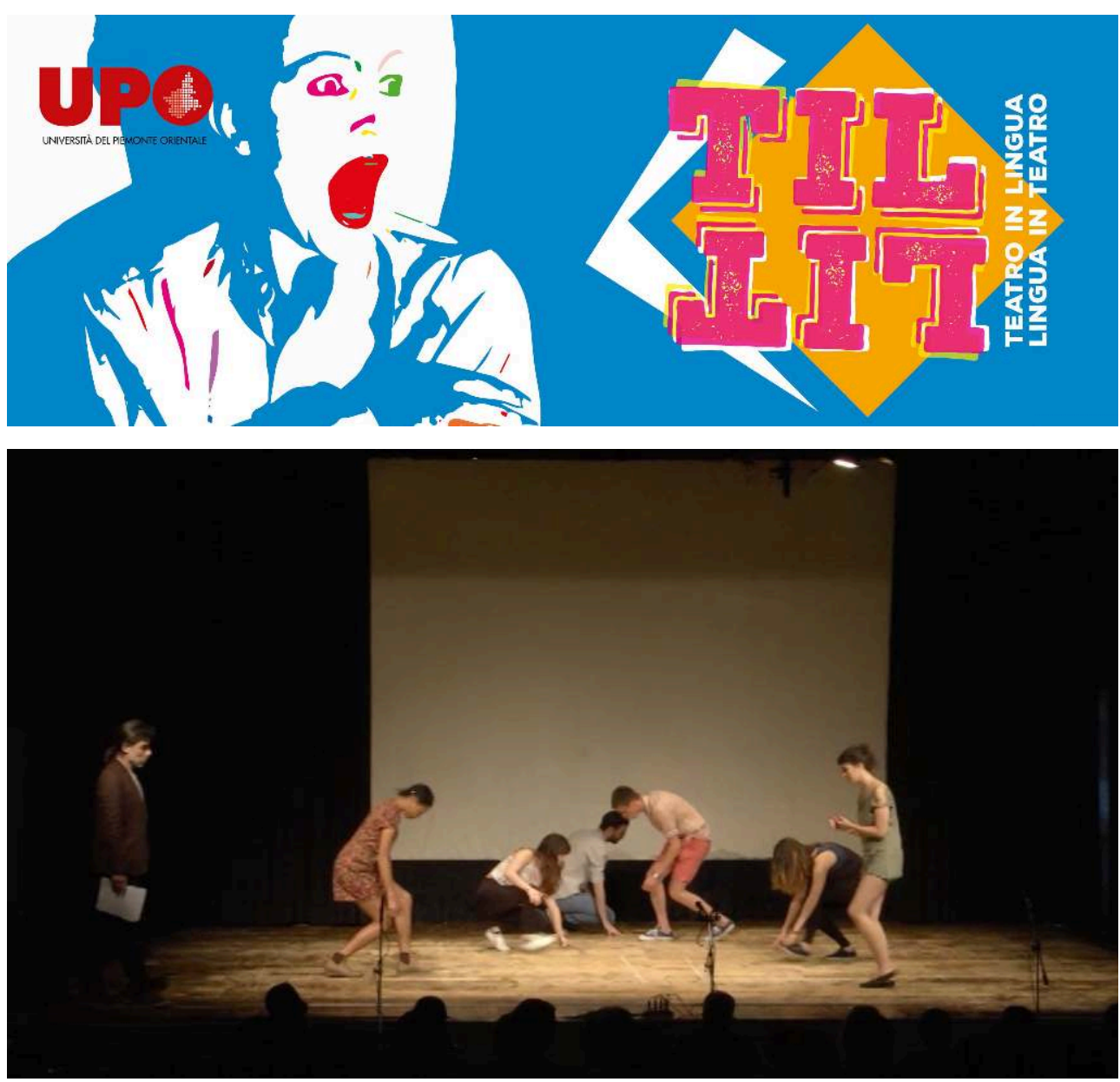


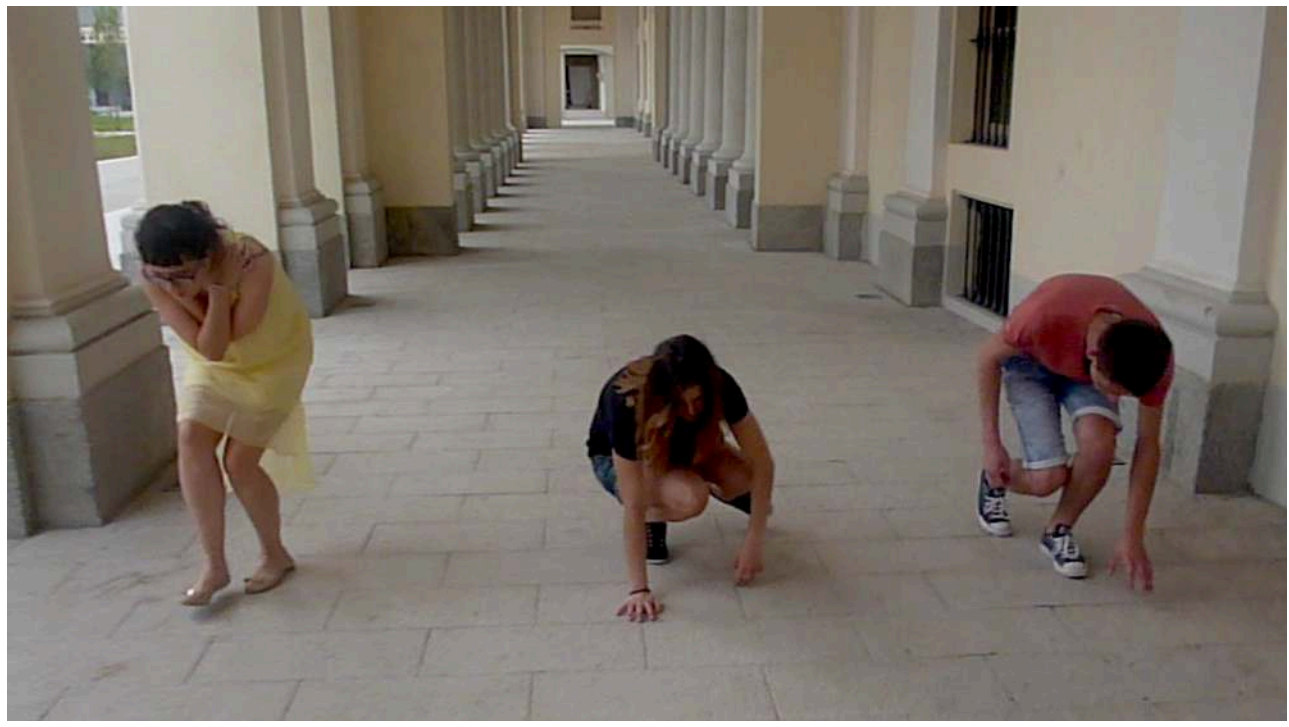

14

Communicative behaviour starts the moment we enter the presence of others.

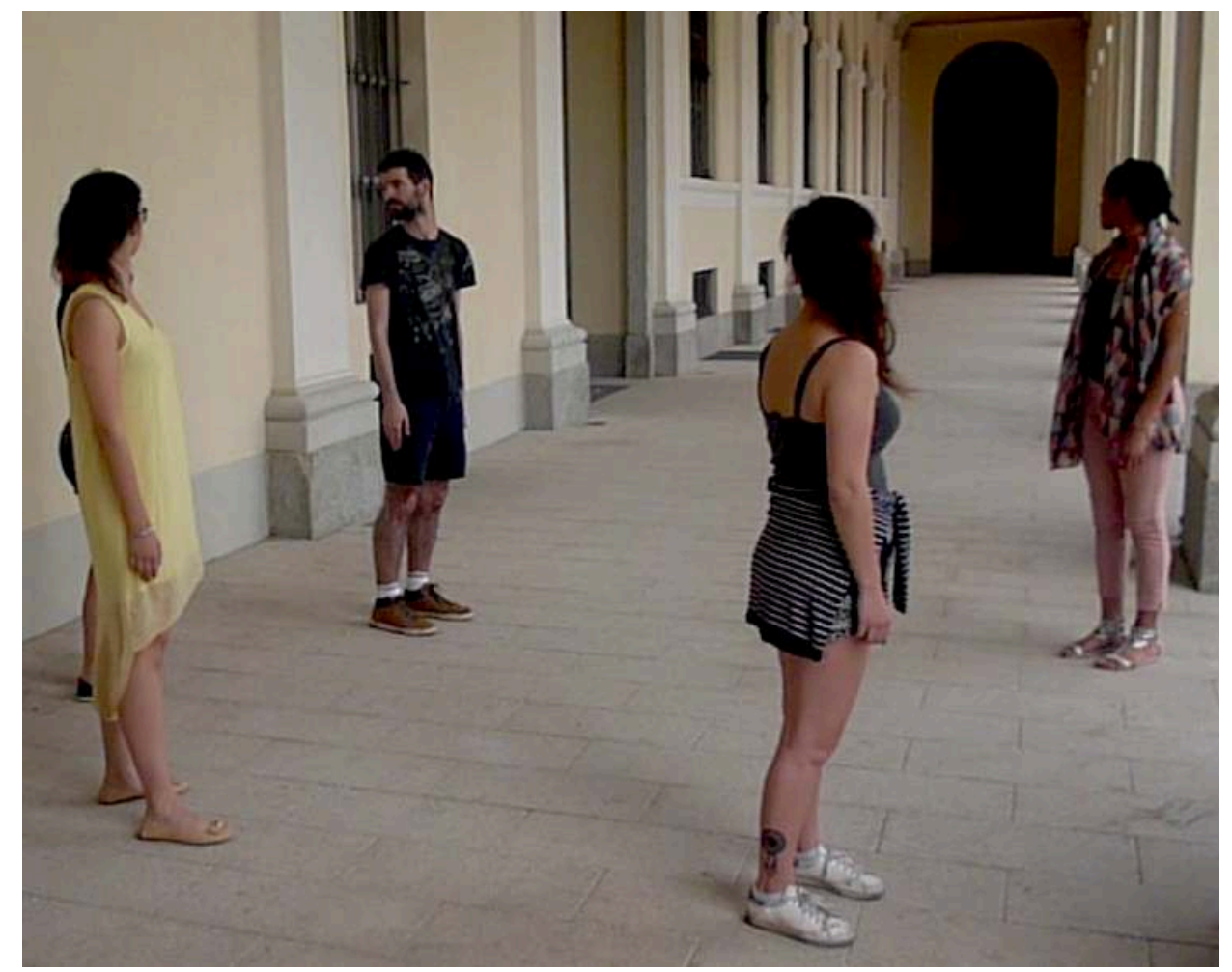



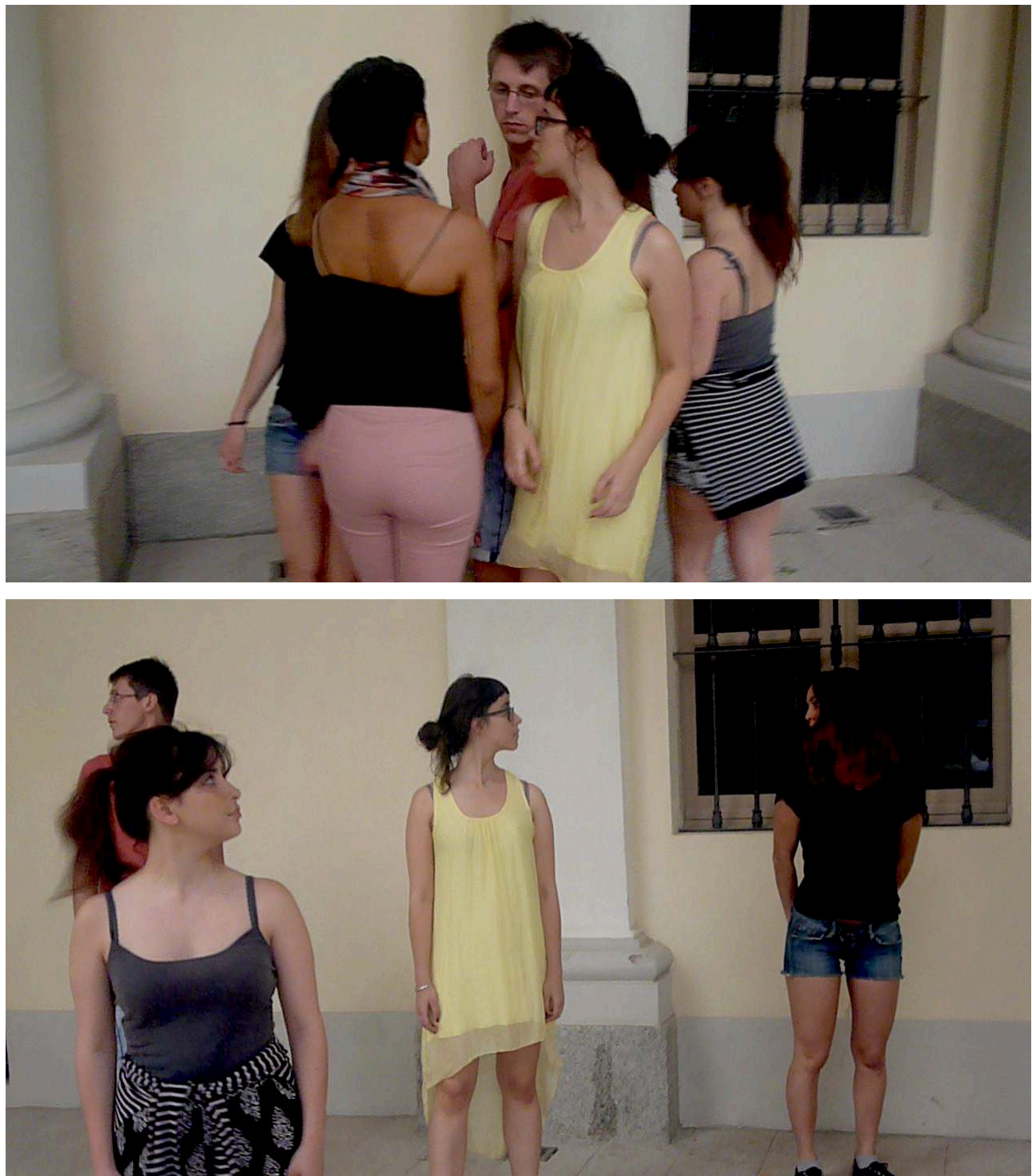

Once in the immediate presence of others, a social situation is created,

filled with embodied expressive signs. 


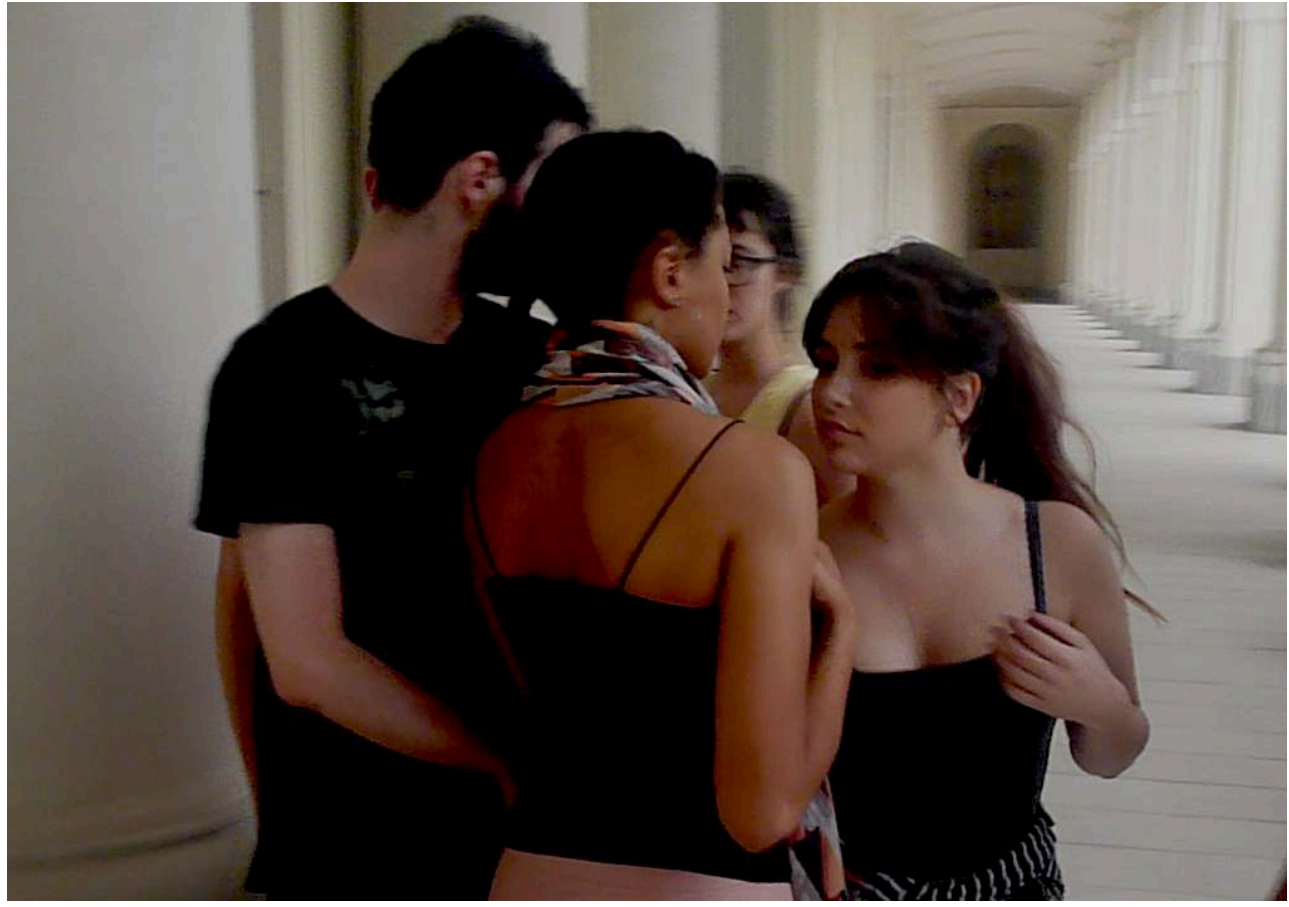

17 Social encounters are behavioral events made up of behavioral material.

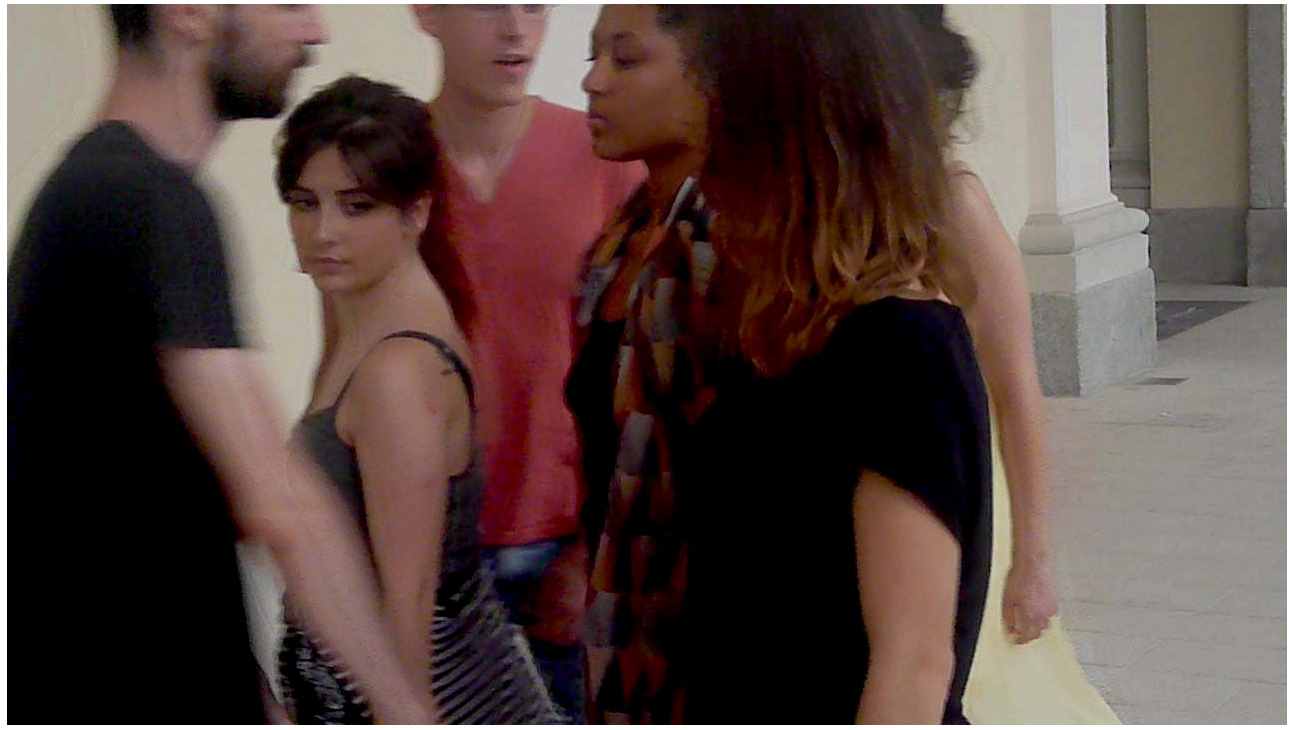

Glances... gestures... postionings.... and verbal statements

are continuously fed into the situation. 


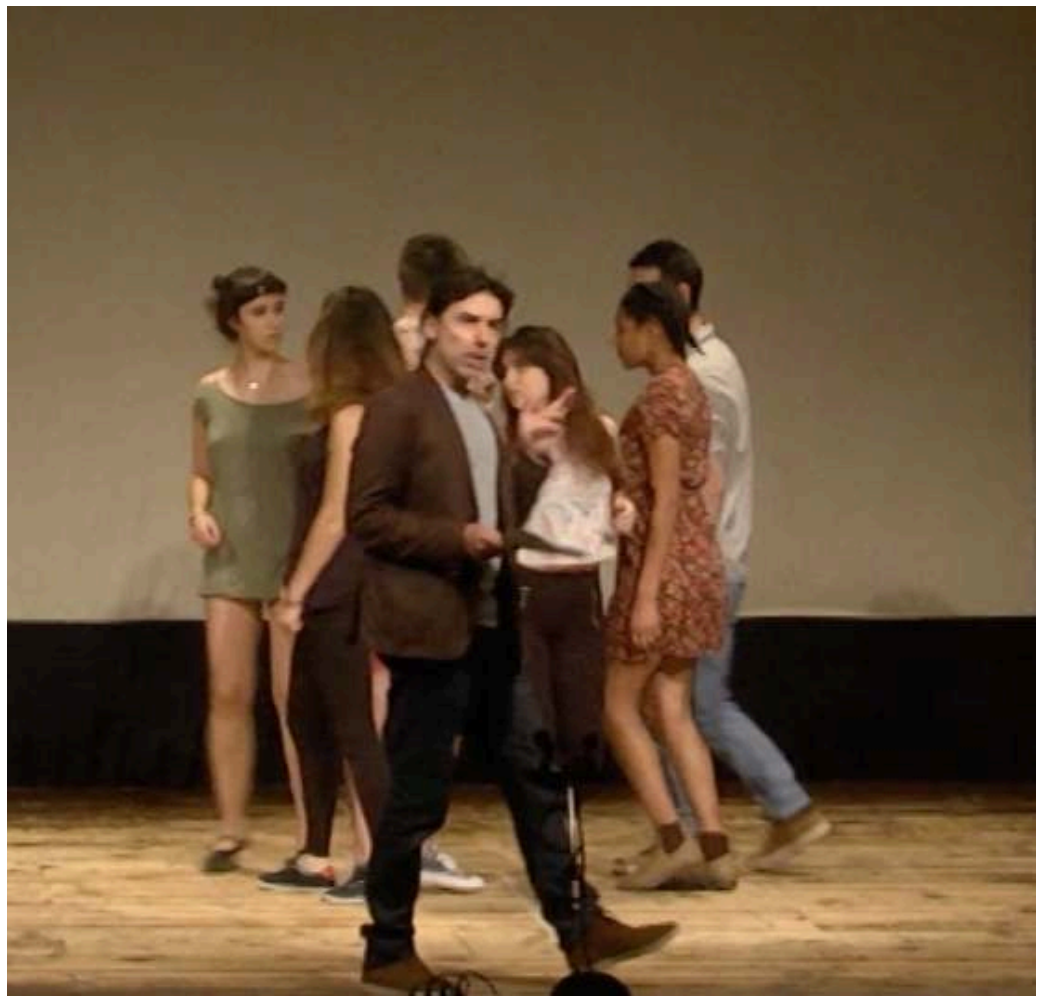

When the expressive behaviour - verbal and non verbaltakes on a ritual character, a little parade is instituted.

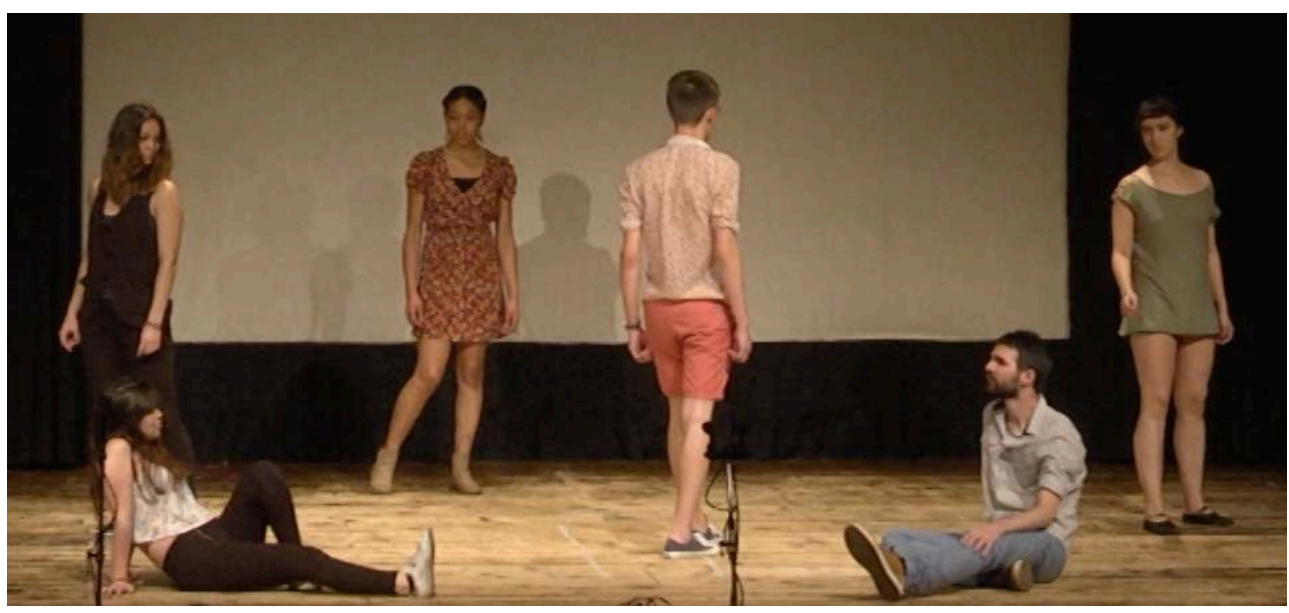

(Little parade $\mathrm{n}^{\circ} 1-$ Greeting rituals) $^{3}$

How do you do, Lady Windermere.

How do you do, Lord Darlington.

25 I'm so pleased to see you. 

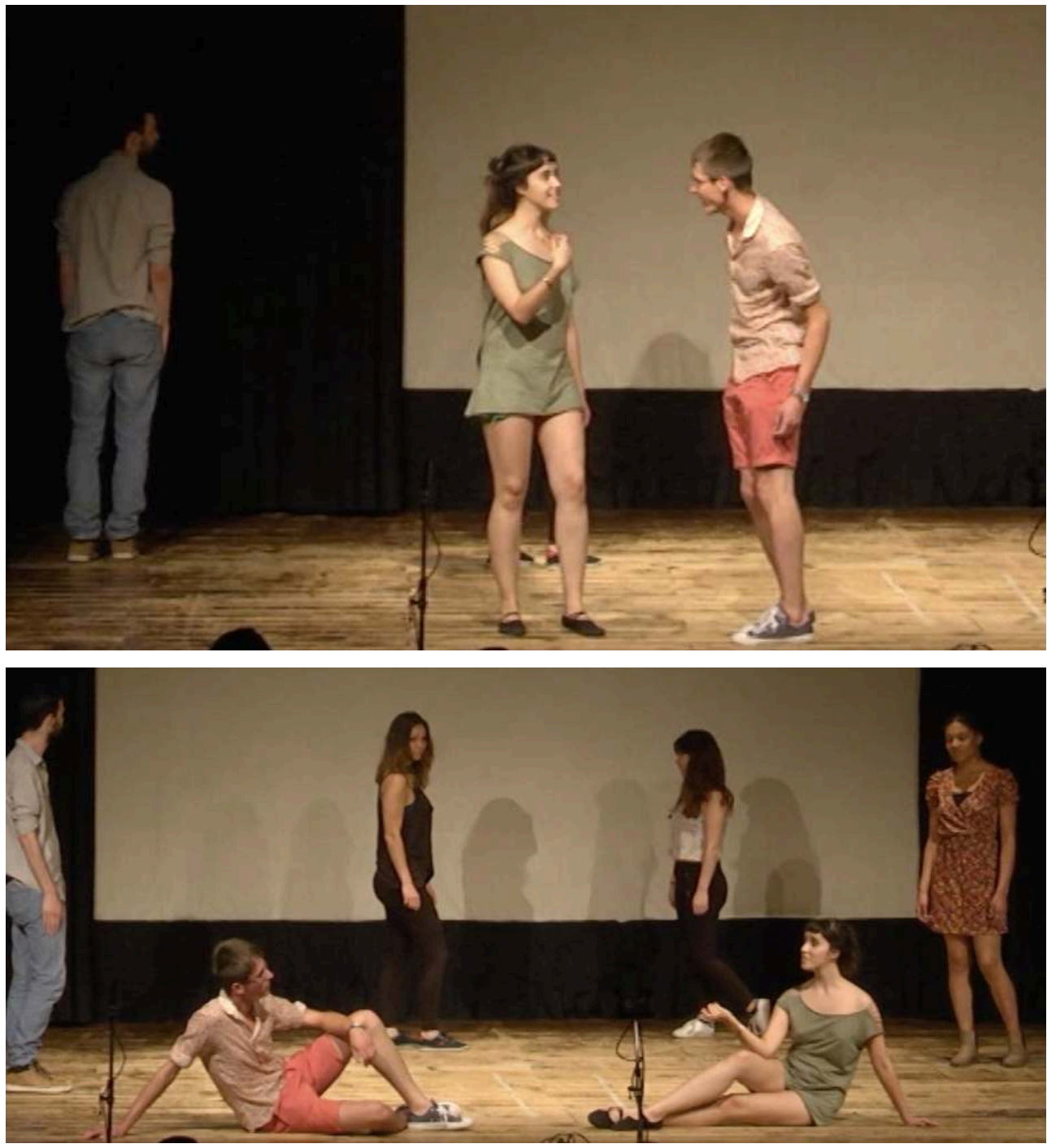

(Little parade $\mathrm{n}^{\circ}$ 2-Compliments) ${ }^{4}$

What a beautiful fan! May I look at it?

Do. It's my husband's birthday present to me.

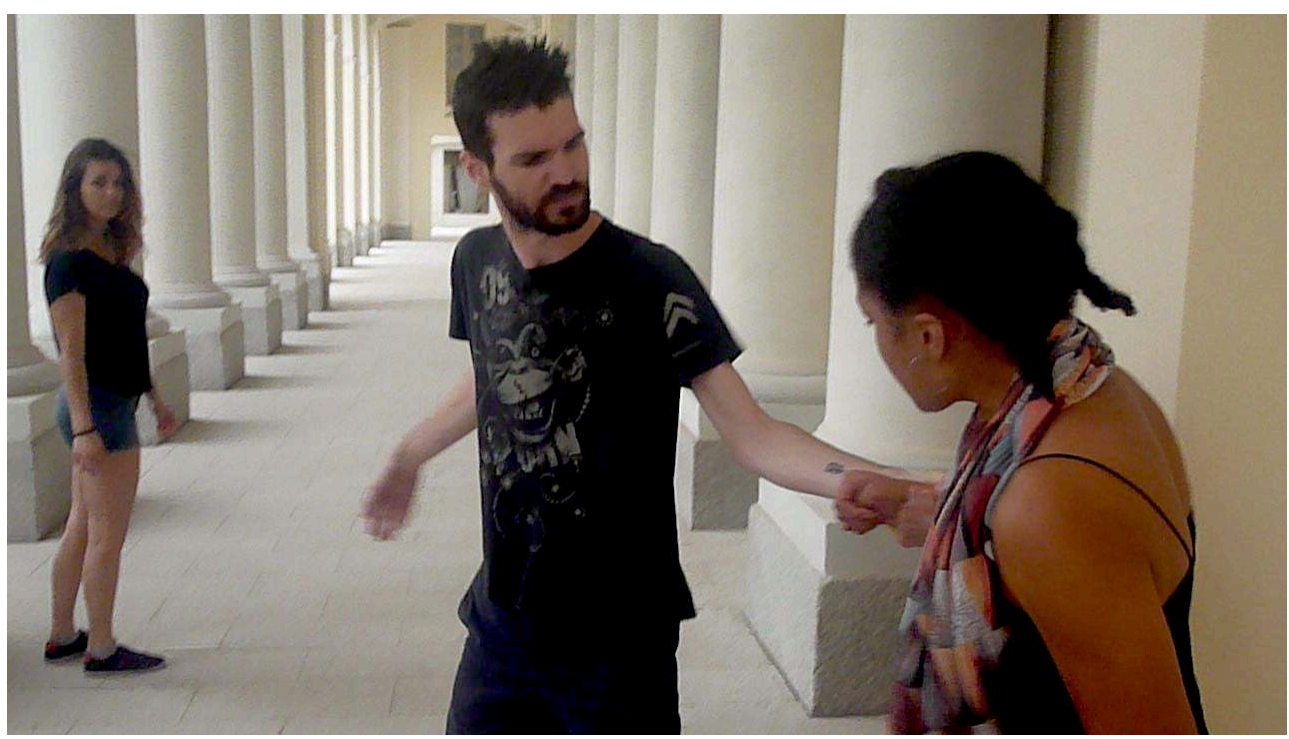




\section{Do let me go, please!}

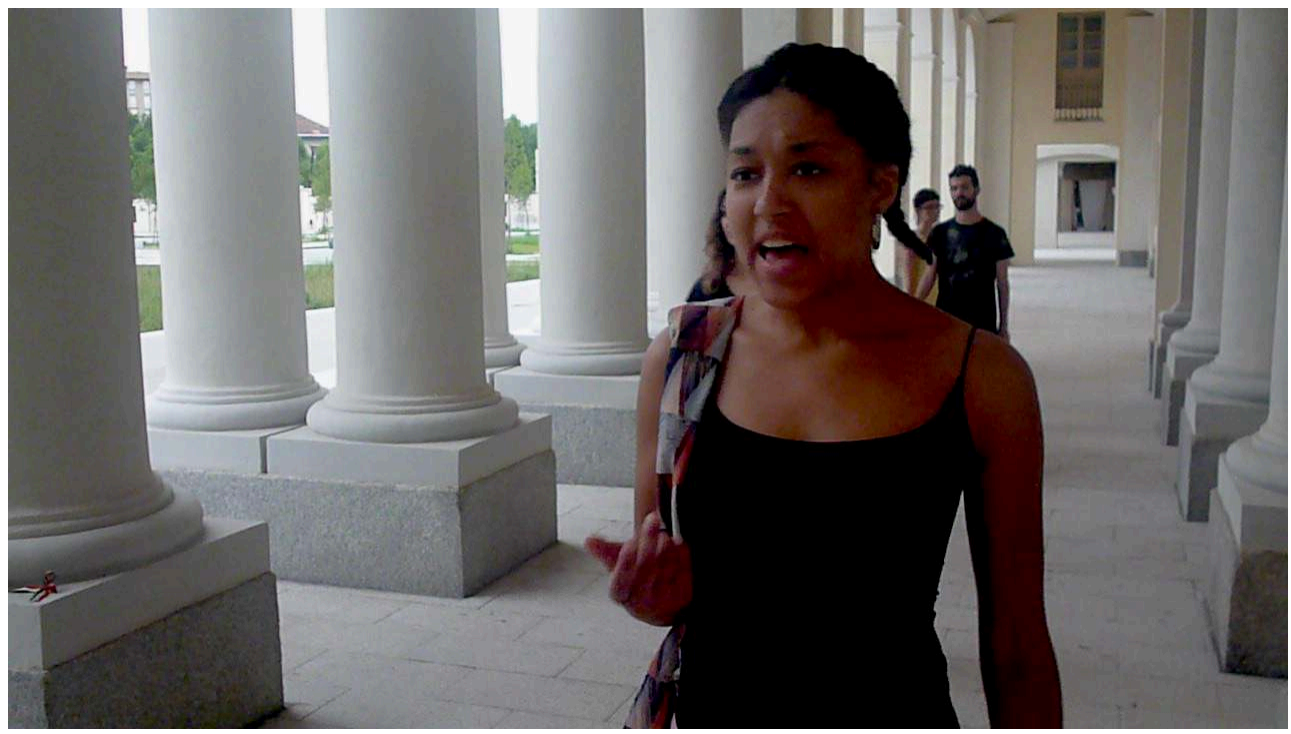

32

But controlling facial muscles and facial expressions is NOT SO EASY.

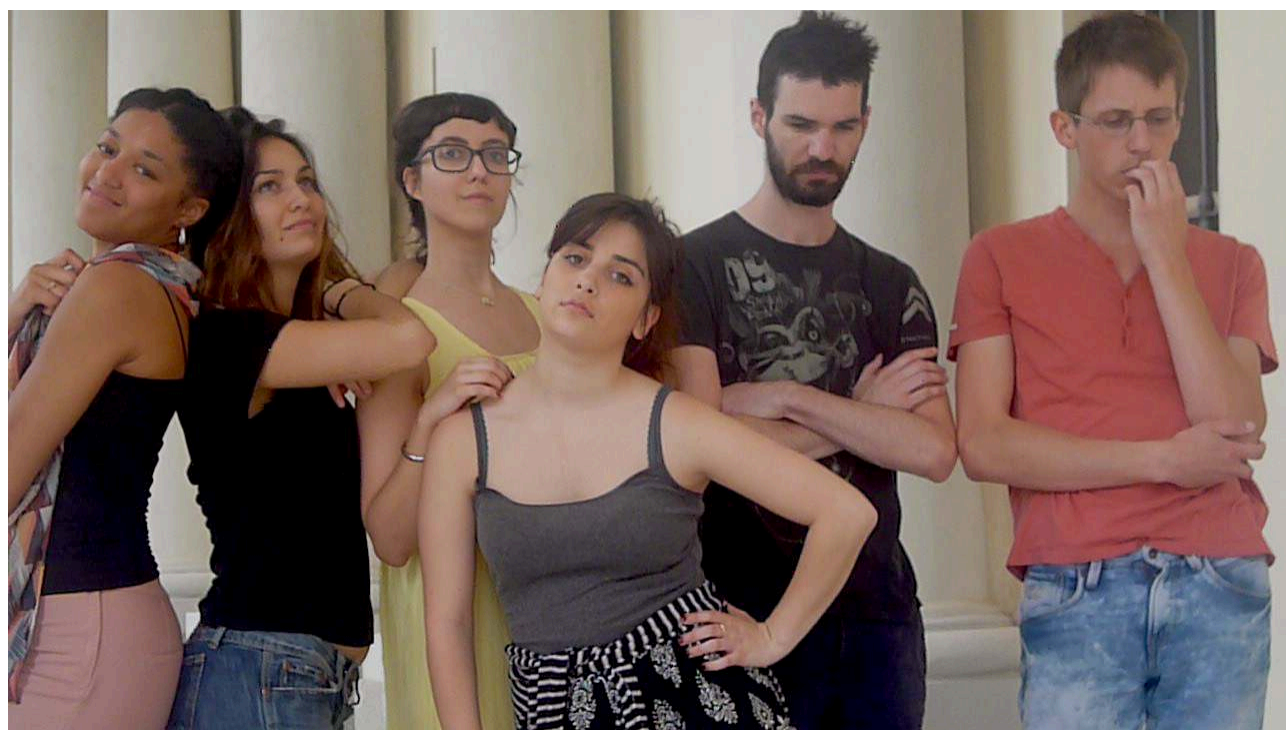



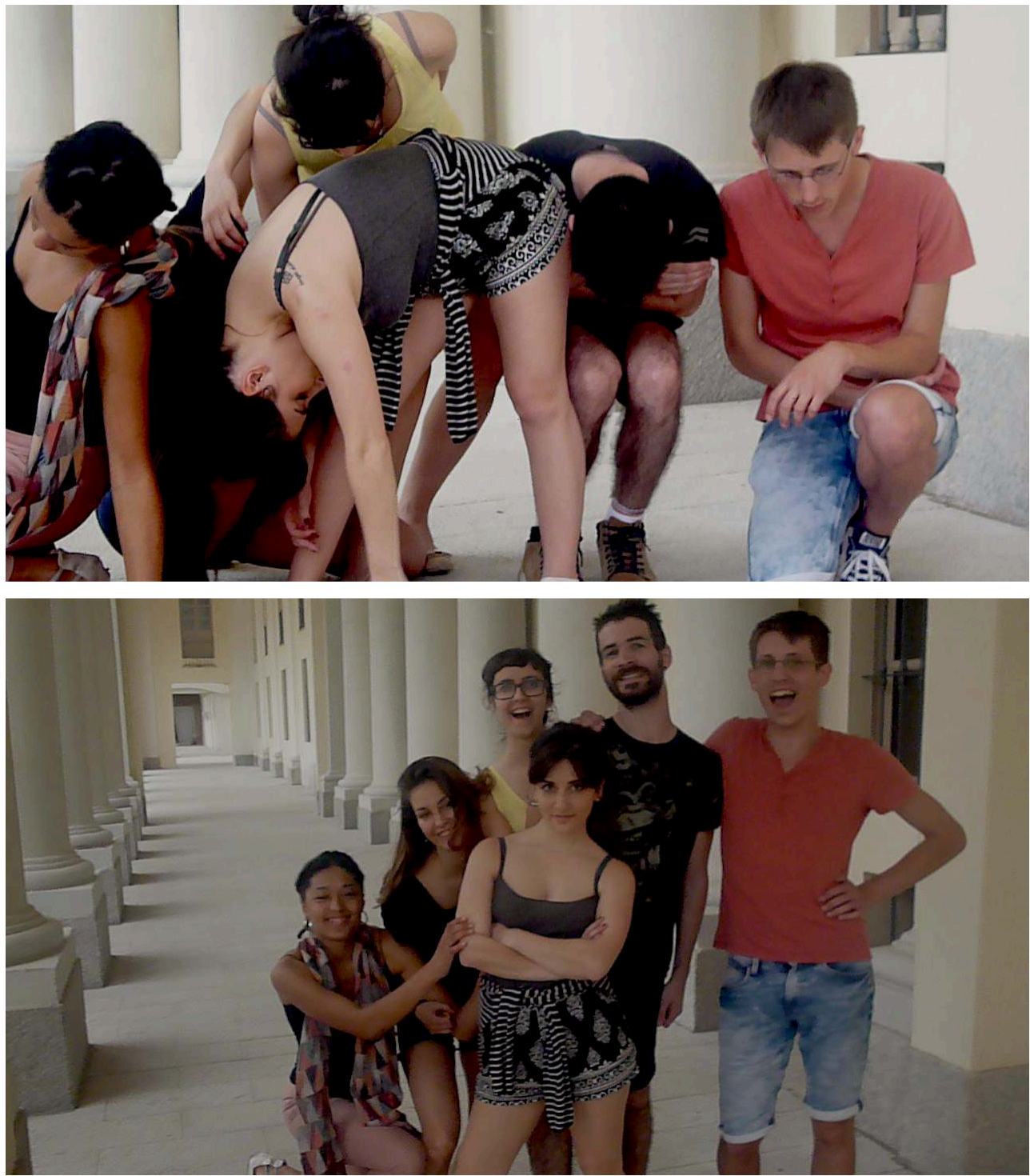

33 We have all sorts of personal and institutional faces. Party faces, funeral faces, school faces, TILLIT Festival faces.

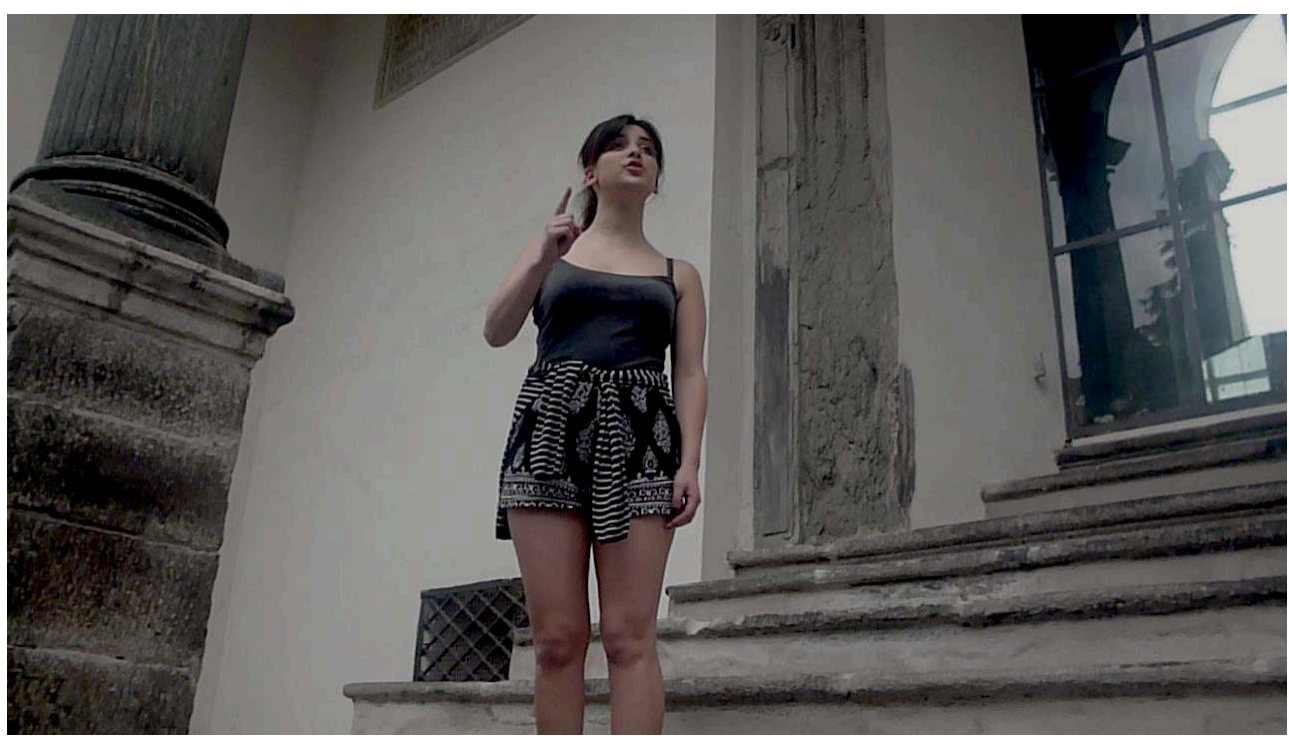




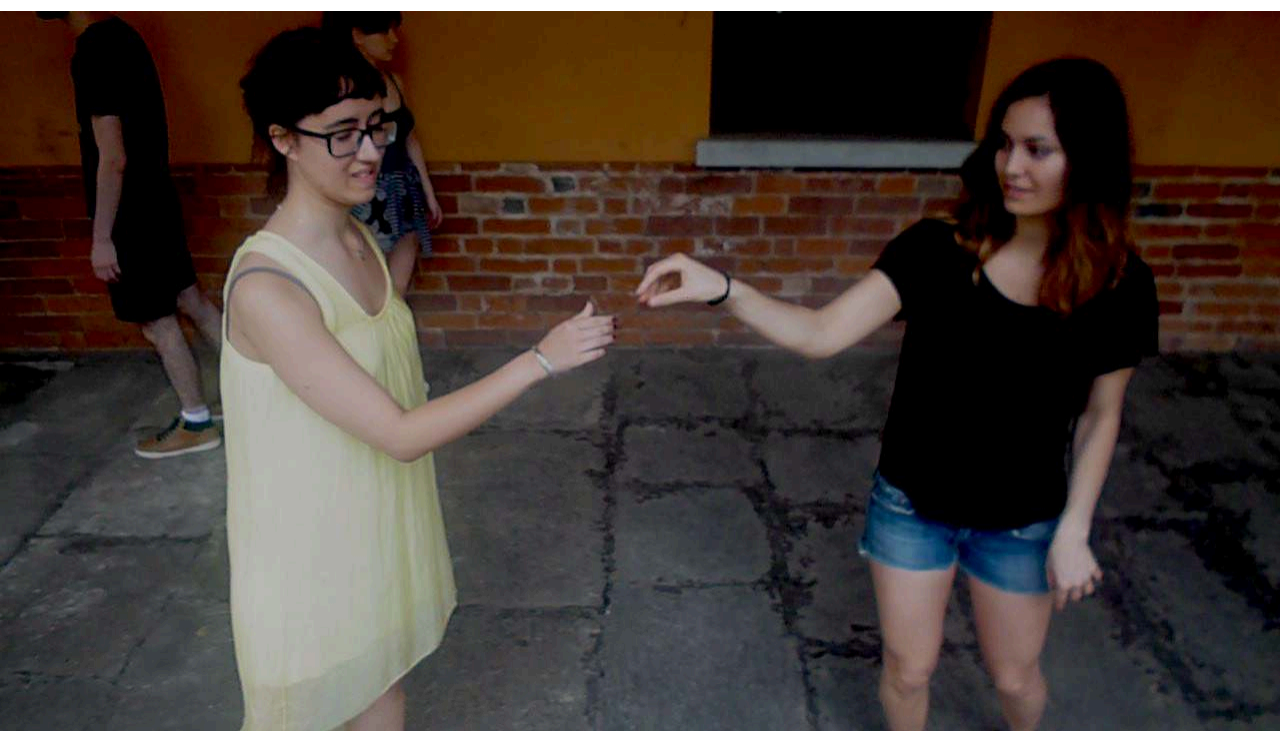

- Let us be great friends!

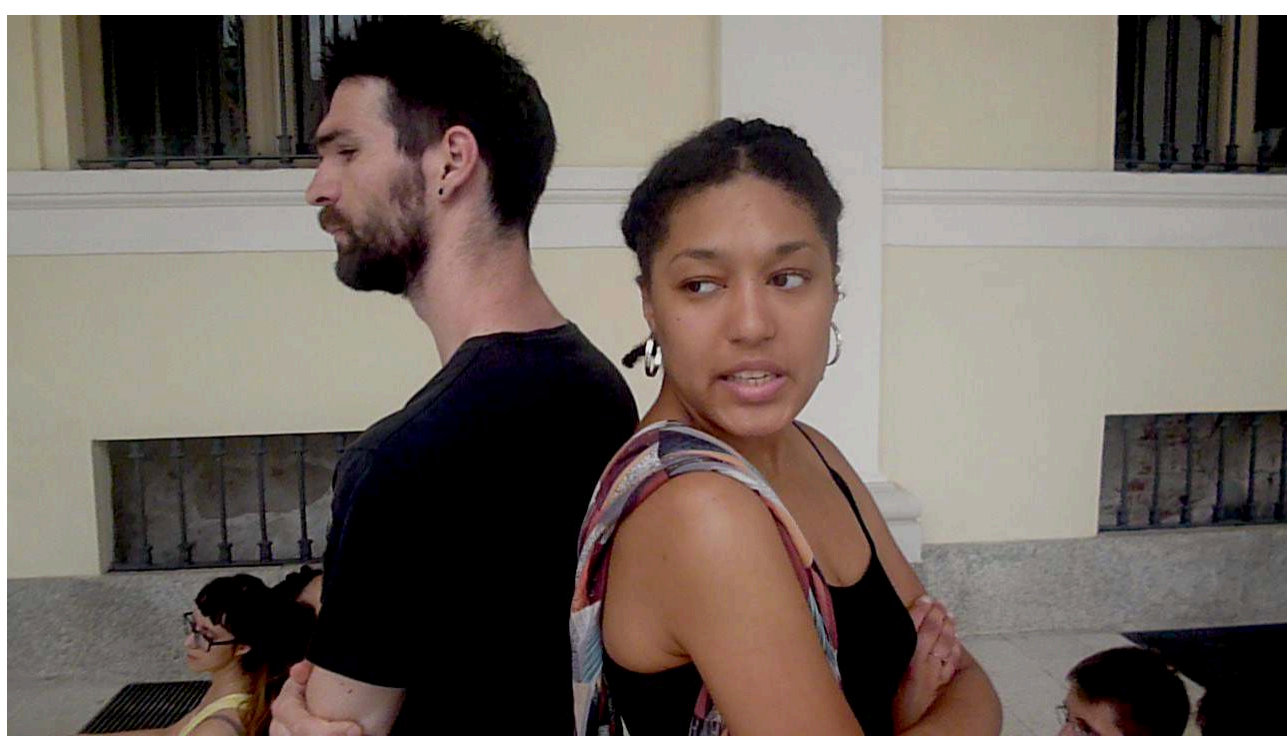

Some of our expressions are consciously given.

\section{We shall have a scandal!}

Others are unconsciously given off?.

Face-to-face interaction is a kind of performance.

speakers are all actors playing a part and telling their lines,

in an endless succession of scenes.

How hard good women are!

How weak bad men are! 


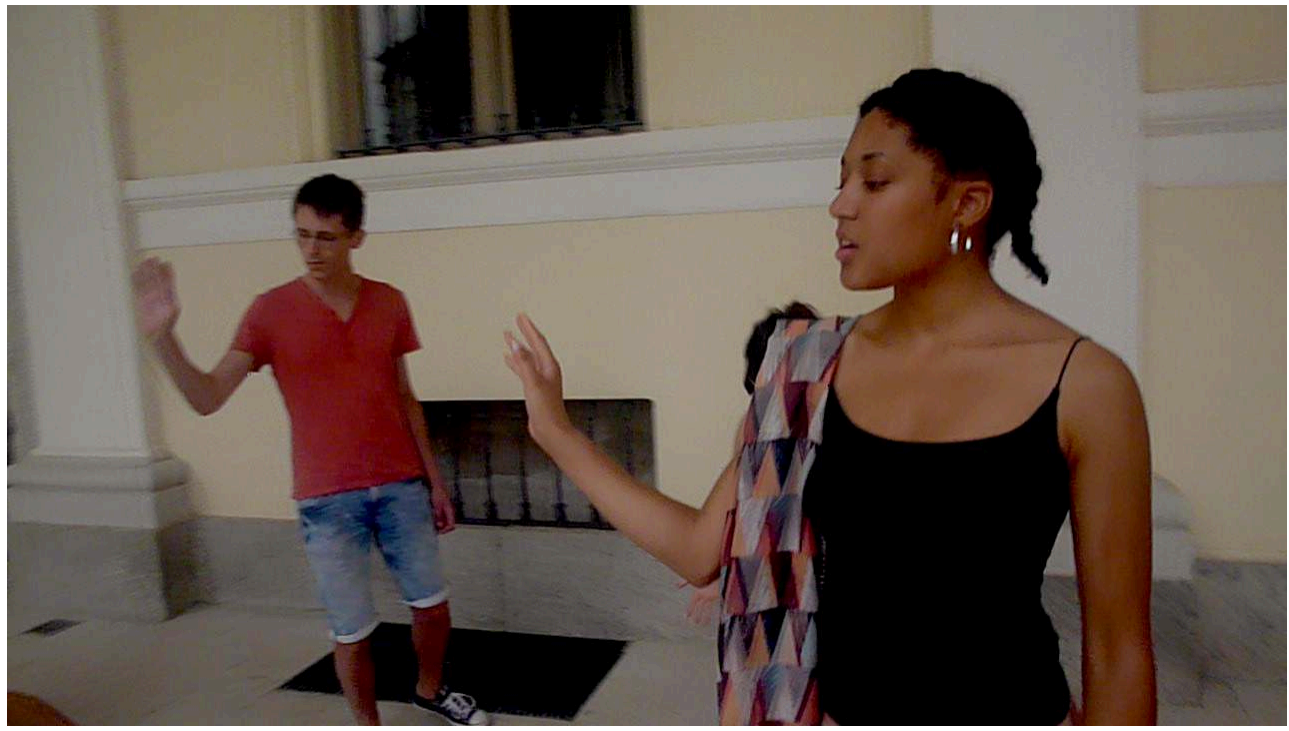

43 Speakers don't just... speak.

44 They act out the meanings they wish to convey.

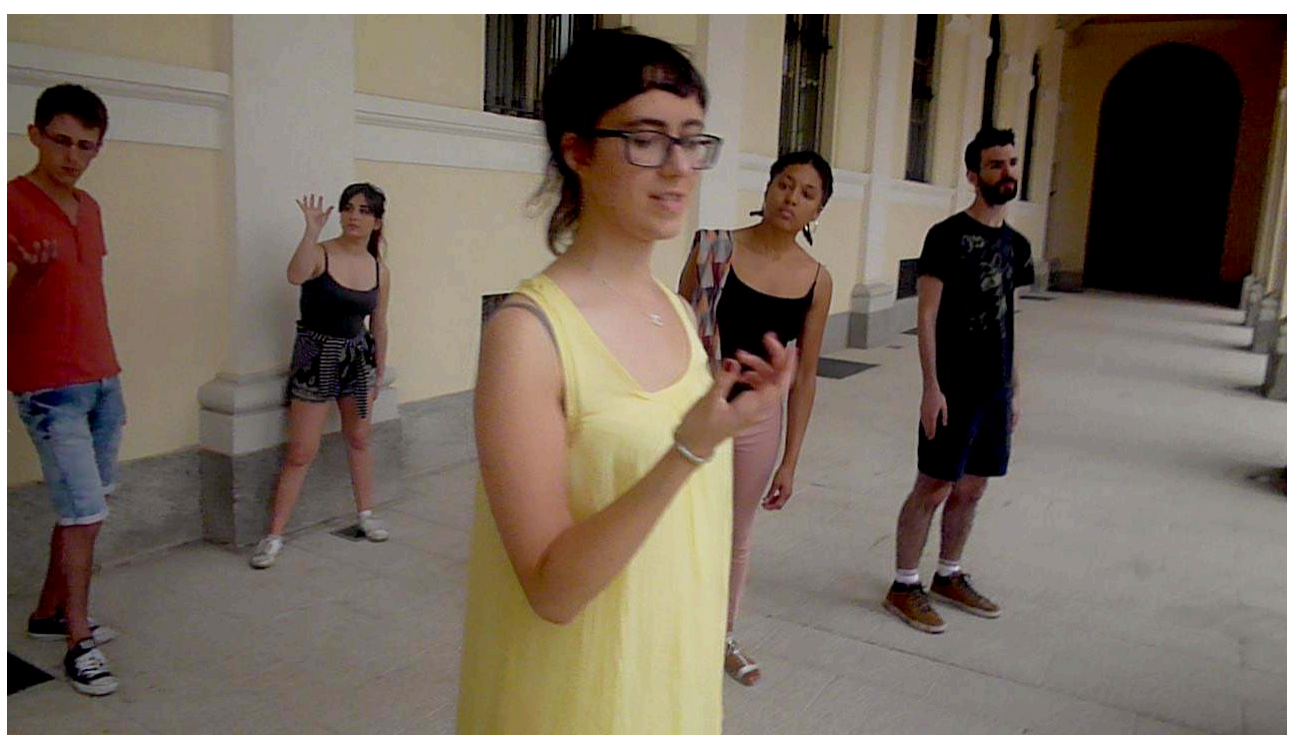

They both say and display. 


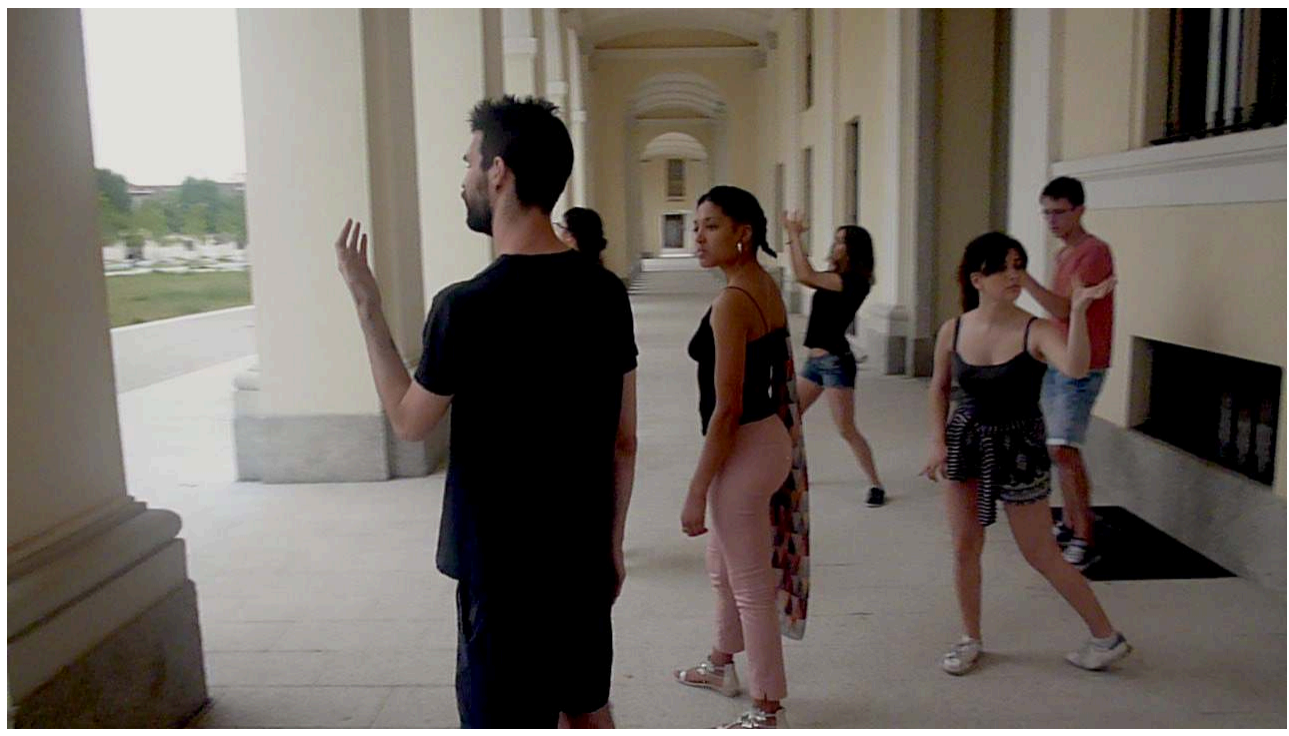

46 - I do not approve of anything that tampers with natural ignorance.

47 - Ignorance is like a delicate exotic fruit. Touch it, and the bloom is gone.

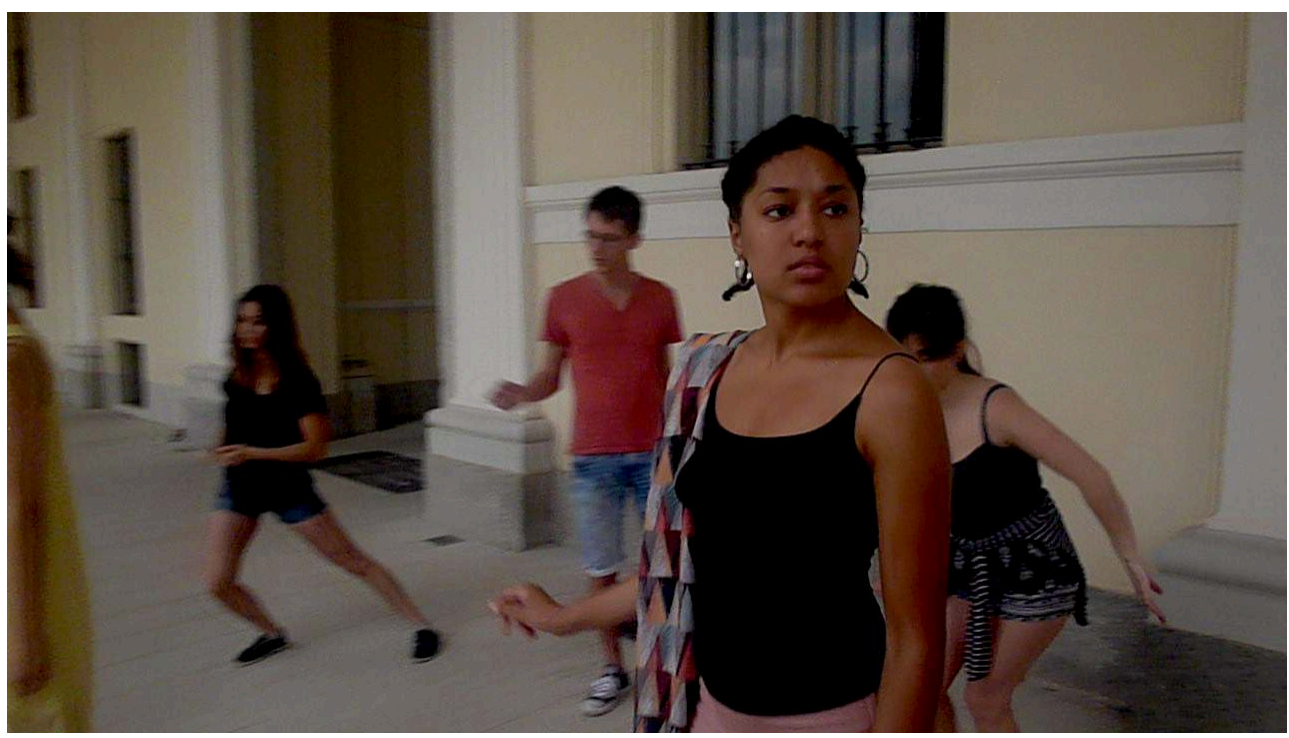

If you want to a learn a second language gracefully then learn to synchronize the vocal system with the kinesic system, or more simply your voice with your moves. ${ }^{6}$ 


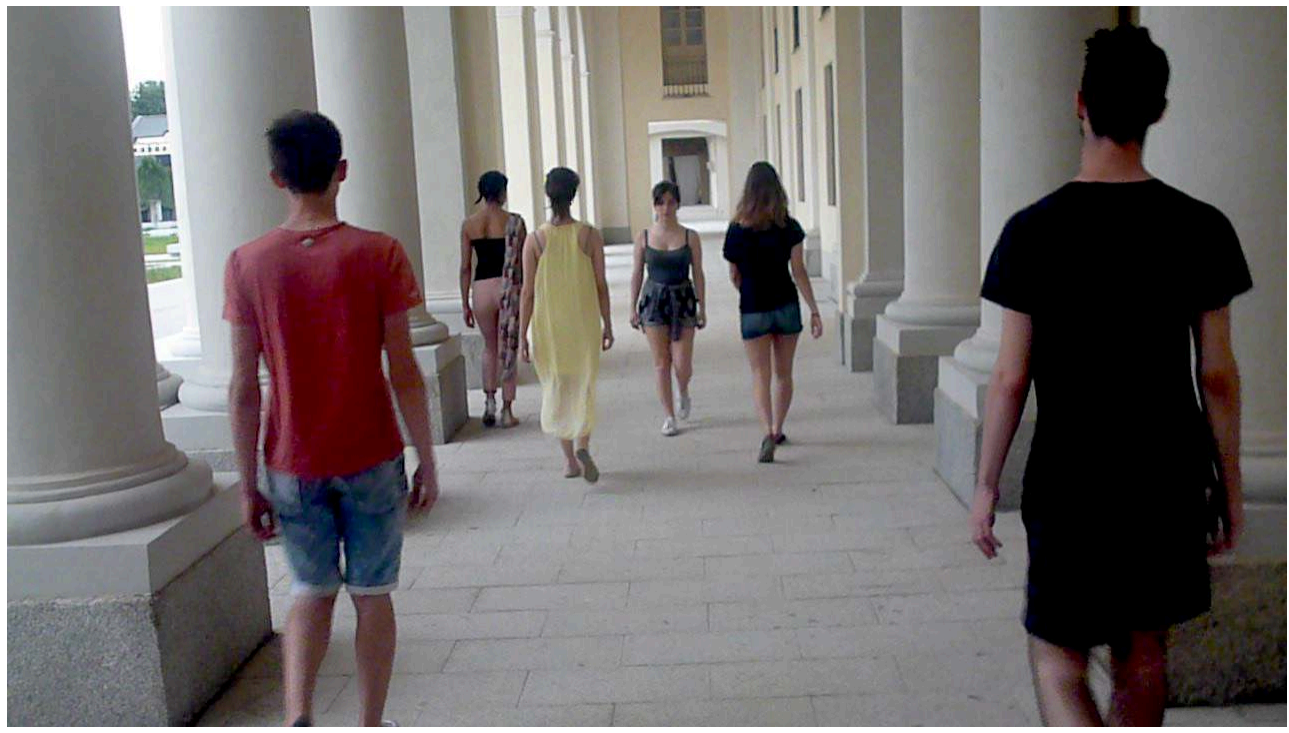

Why do you talk so trivially about life?

Because I think that life is far too important a thing ever to talk seriously about it.

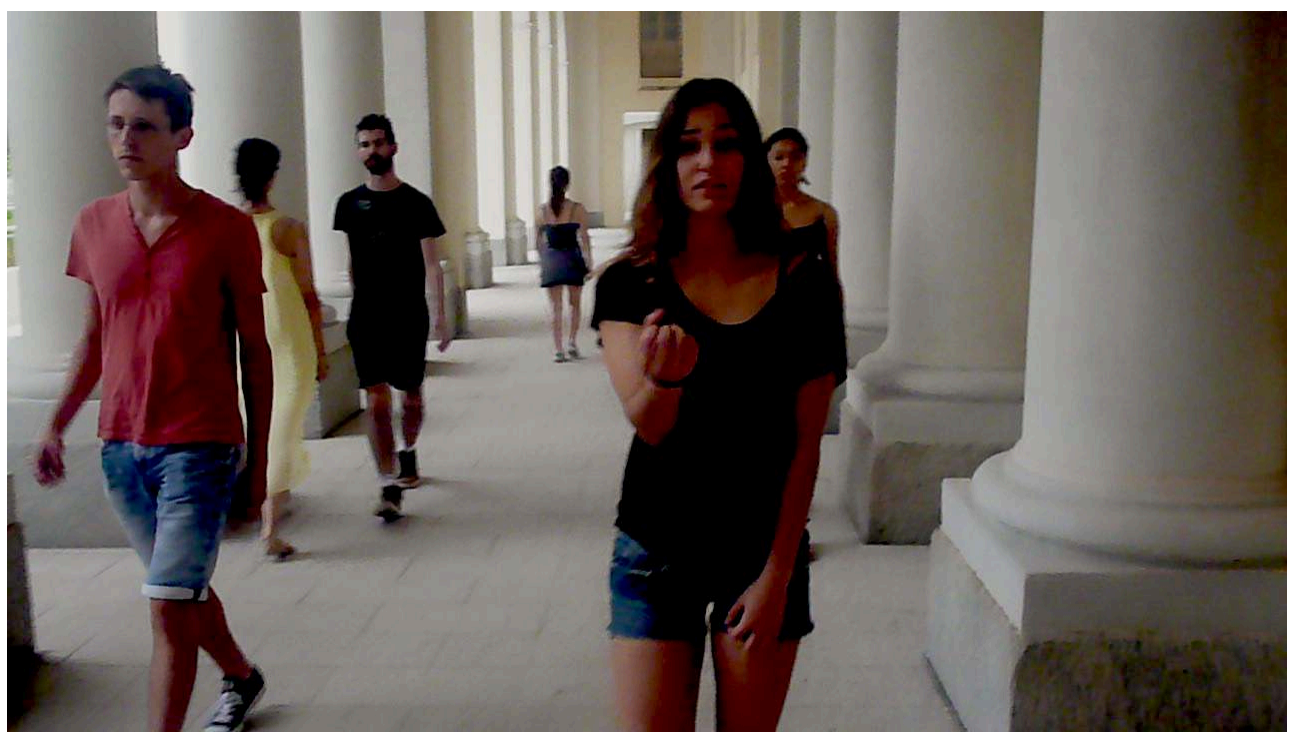

51 - Nowadays people seem to look on life as a speculation.

52 It is not a speculation. It is a sacrament.

53 Its ideal is love. Its purification sacrifice! 


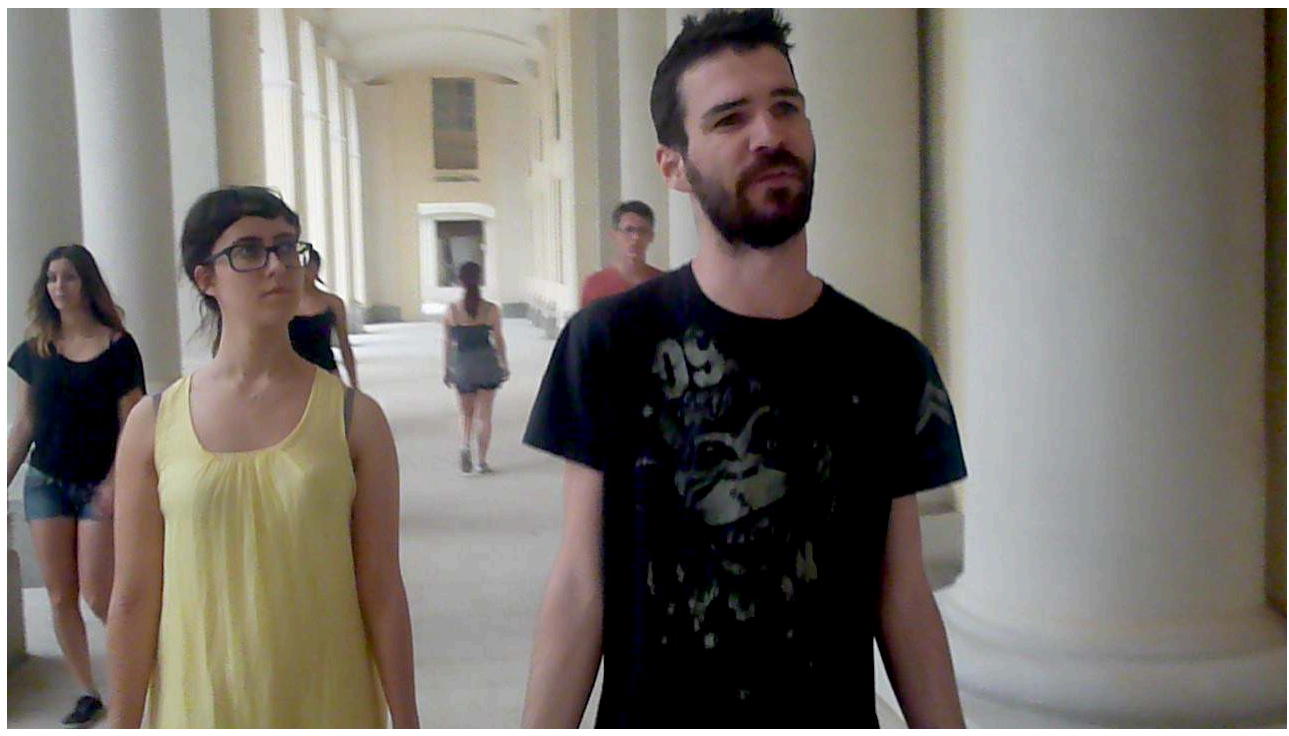

54 - Life is too complex a thing to be settled by hard and fast rules.

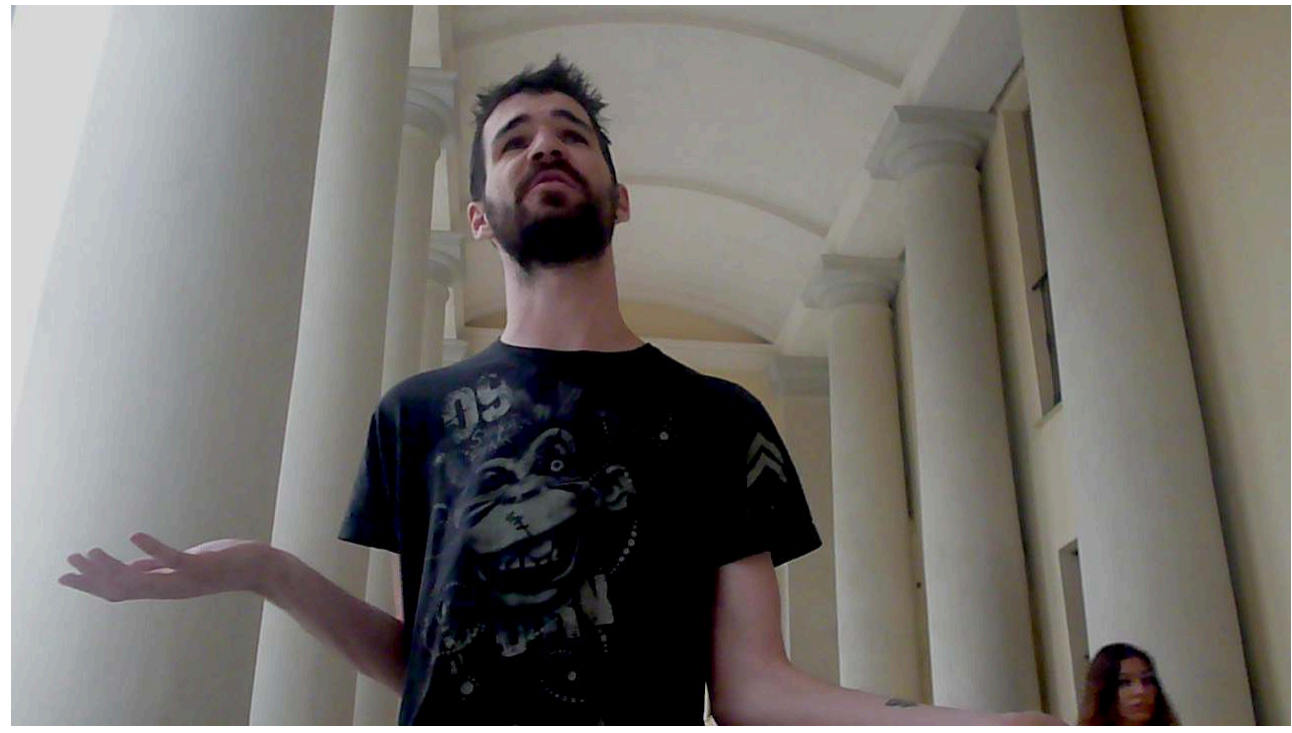

55 - It is absurd to divide people into good and bad.

56 People are either charming or tedious. 


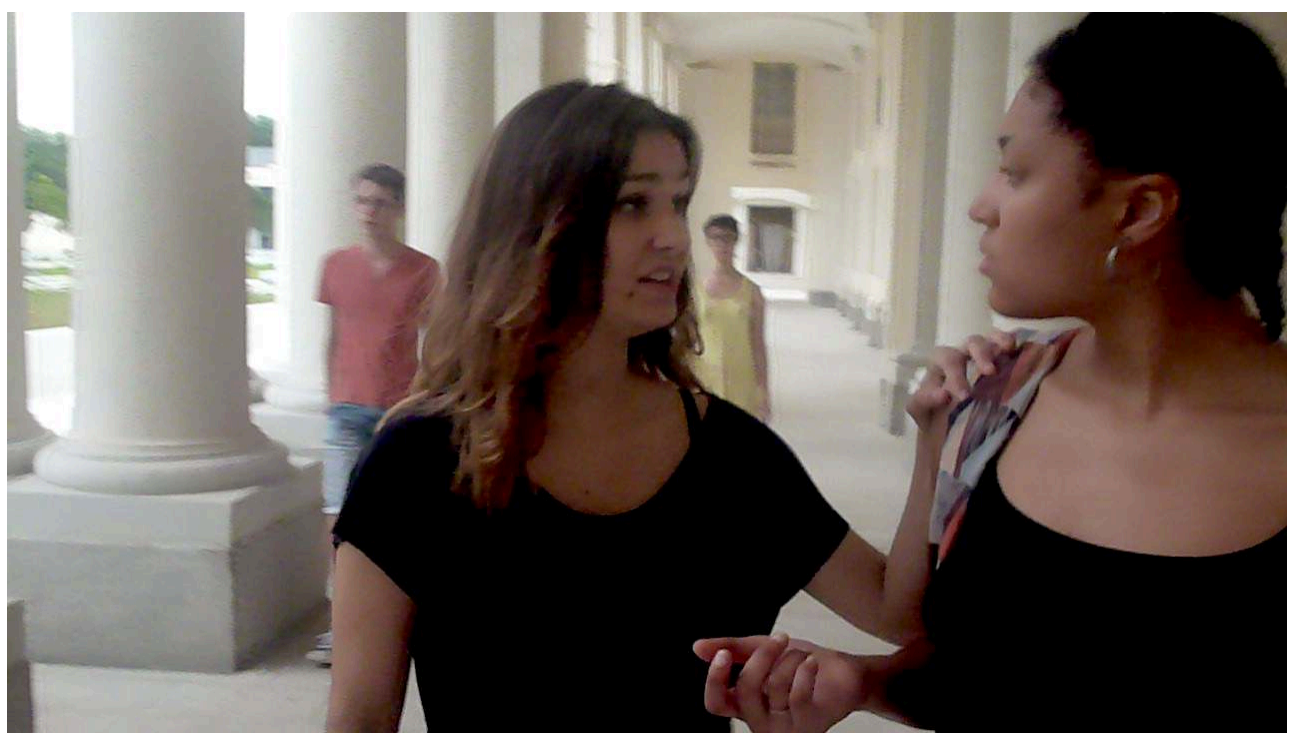

57 - Are all men bad?

58 - Oh, all of them, my dear, without any exception!

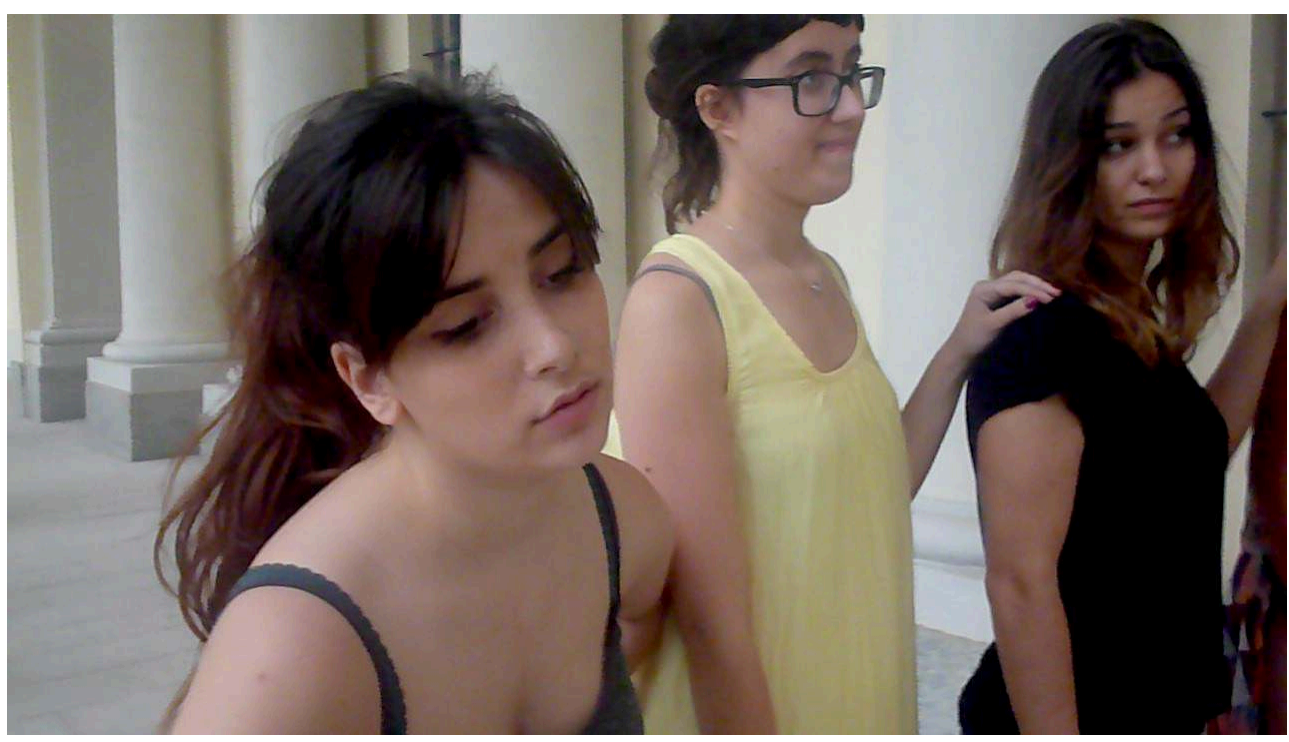

59 And they never grow any better.

60 Men become old, but they never become good. 


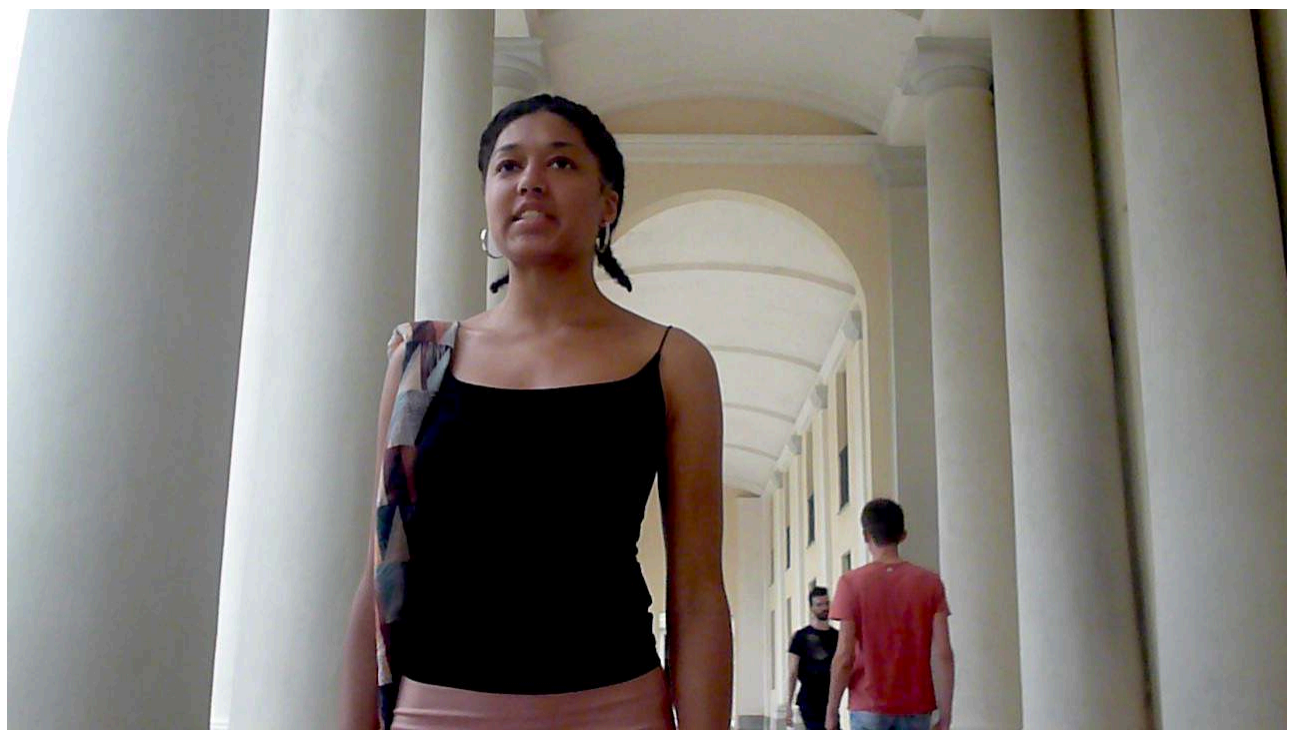

61 - I don't like compliments, and I don't see why a man should think he is pleasing a woman enormously when he says to her a whole heap of things that he doesn't mean.

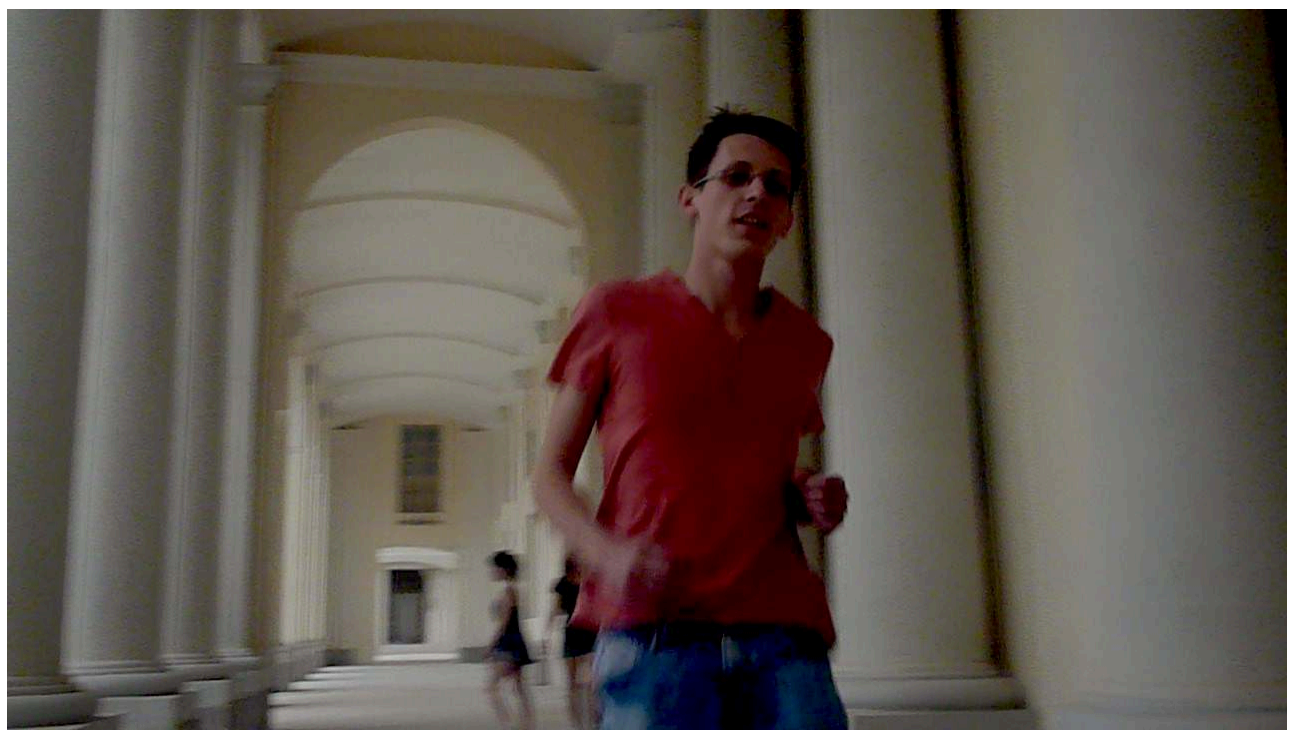

I can resist everything except temptation. 


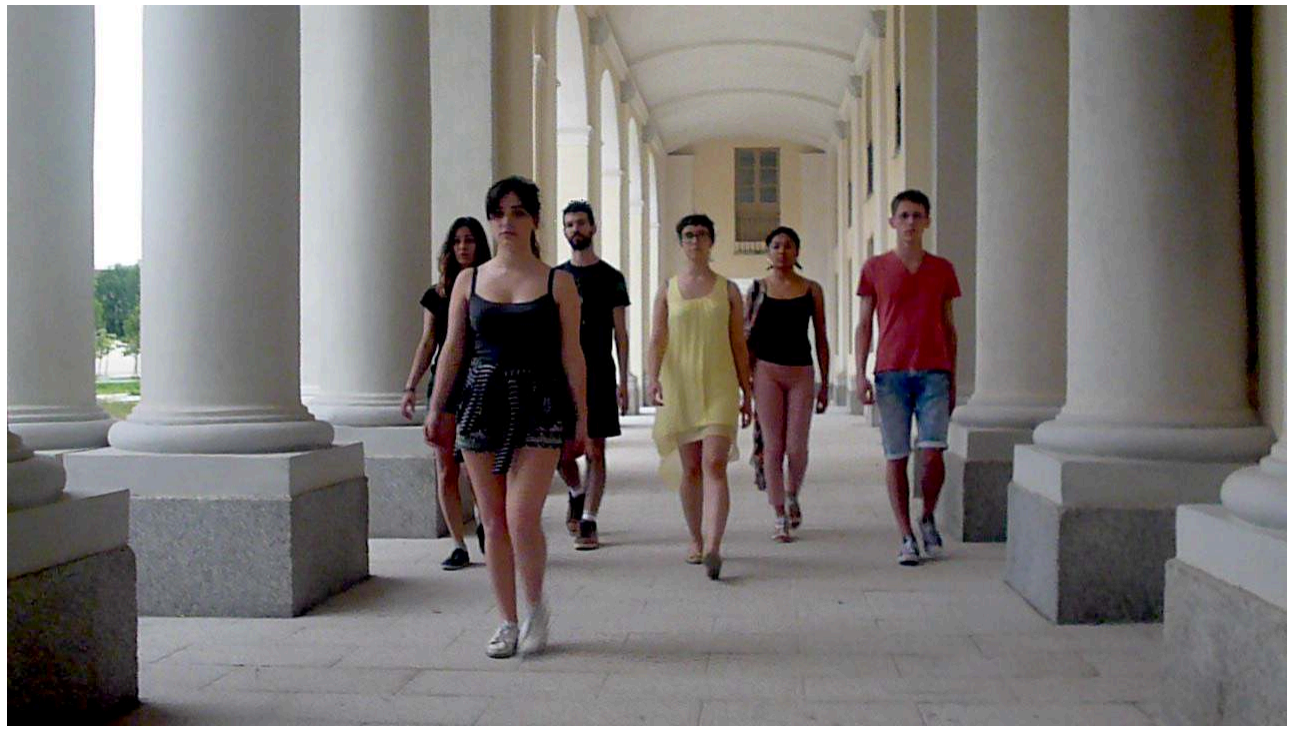

In short, language is orchestrated to a choreography of the human body ${ }^{7}$.

Bonus. A choreographer's work: Jean Magnard and the performers at the Arts Centre (Maison des Arts - Université Bordeaux Montaigne, France).

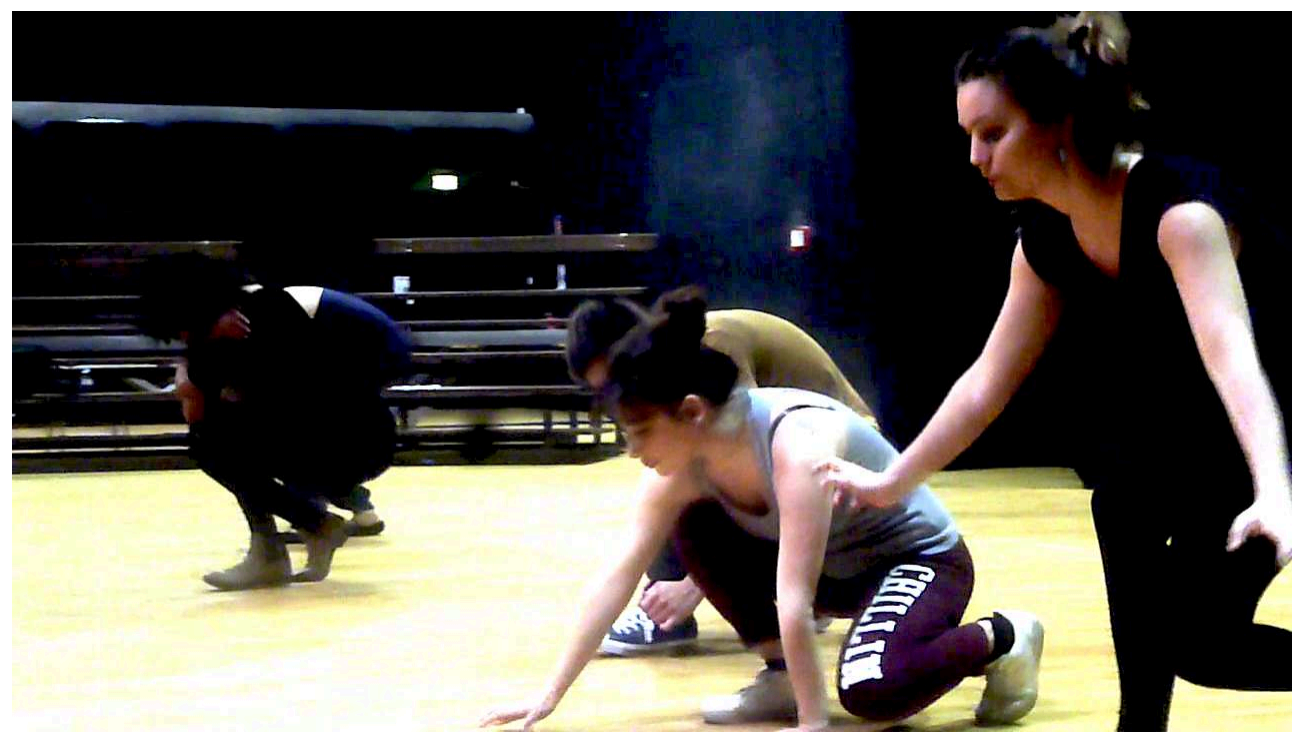

65 Slowly going down to the ground 


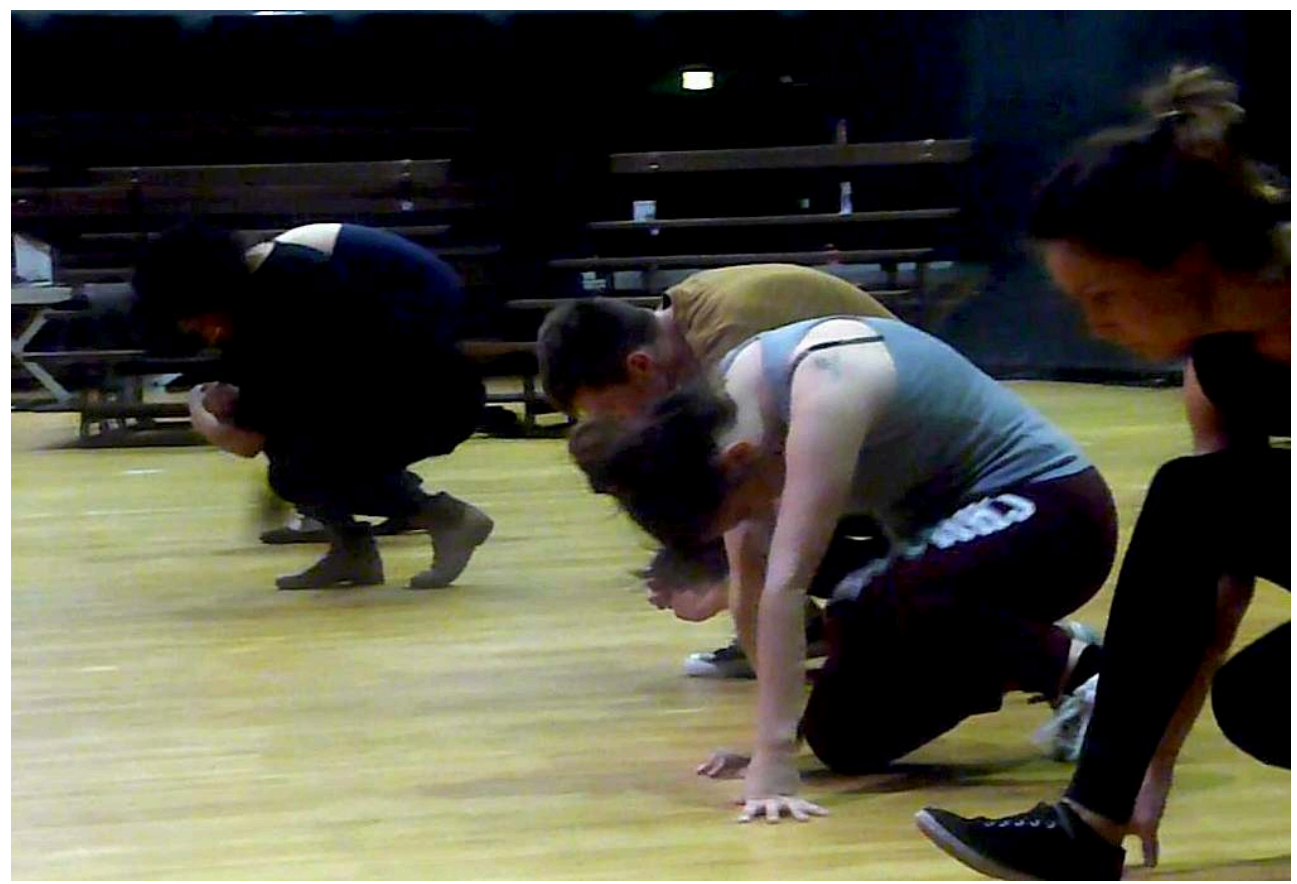

Disappearing gradually...

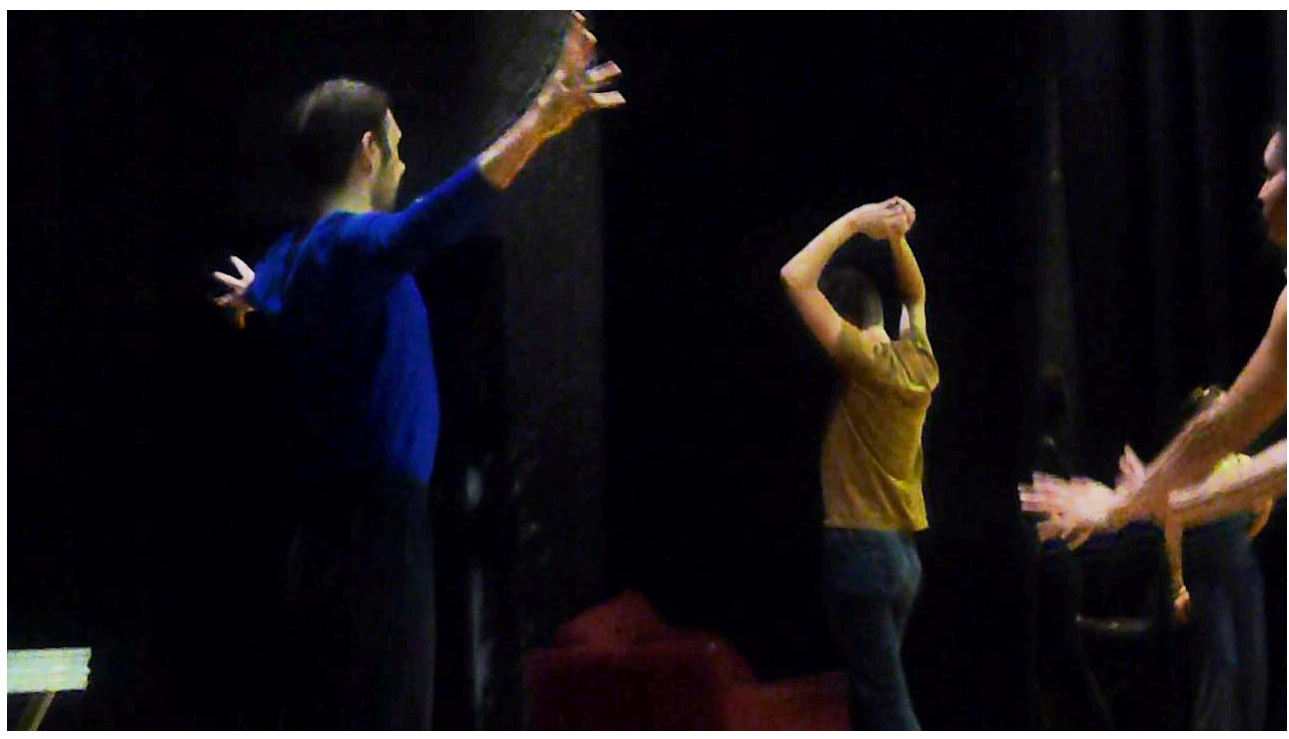

67 ... then coming back to life again, reaching out to the world 


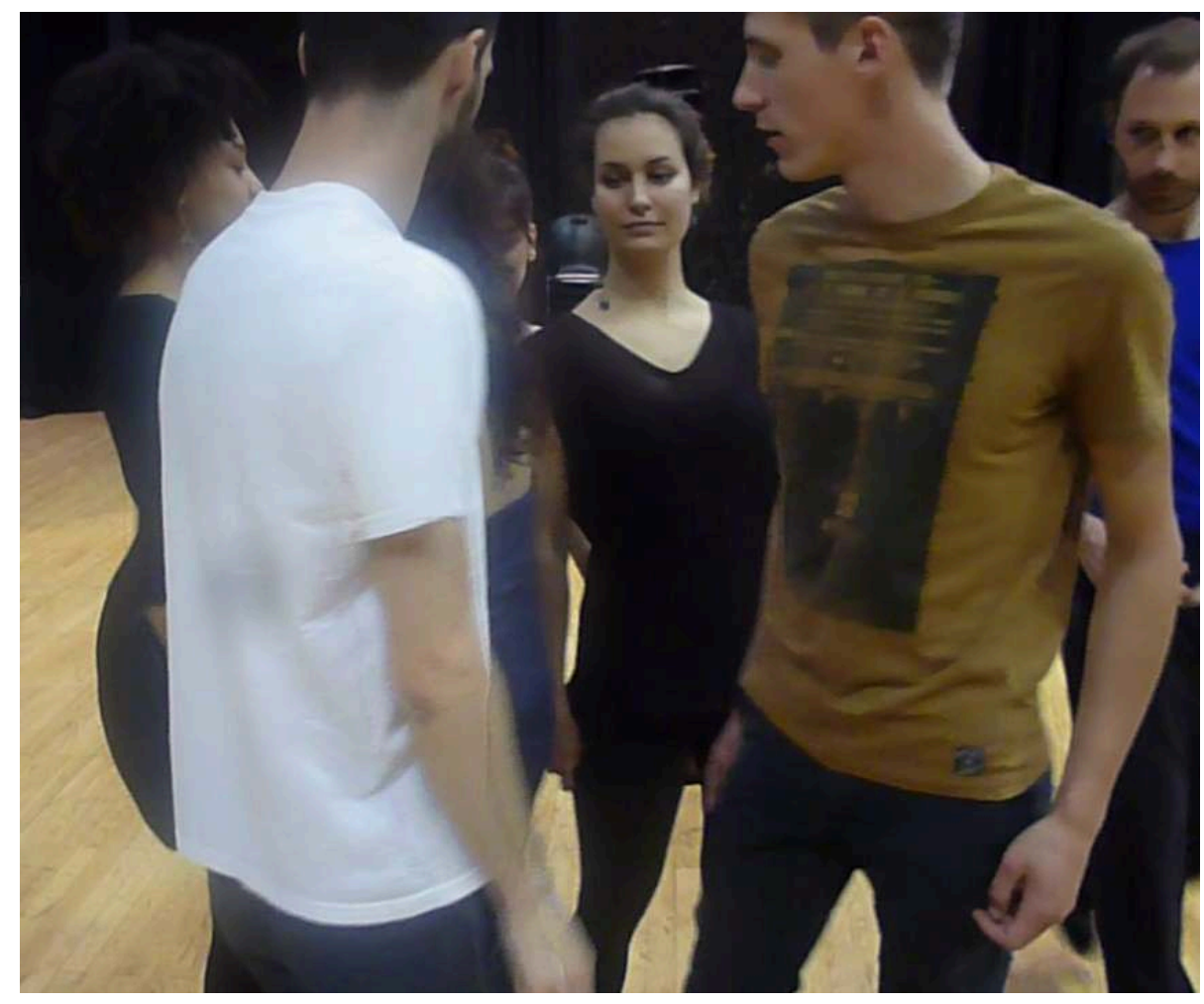

68 Walking round in small circles, making swift eye contact

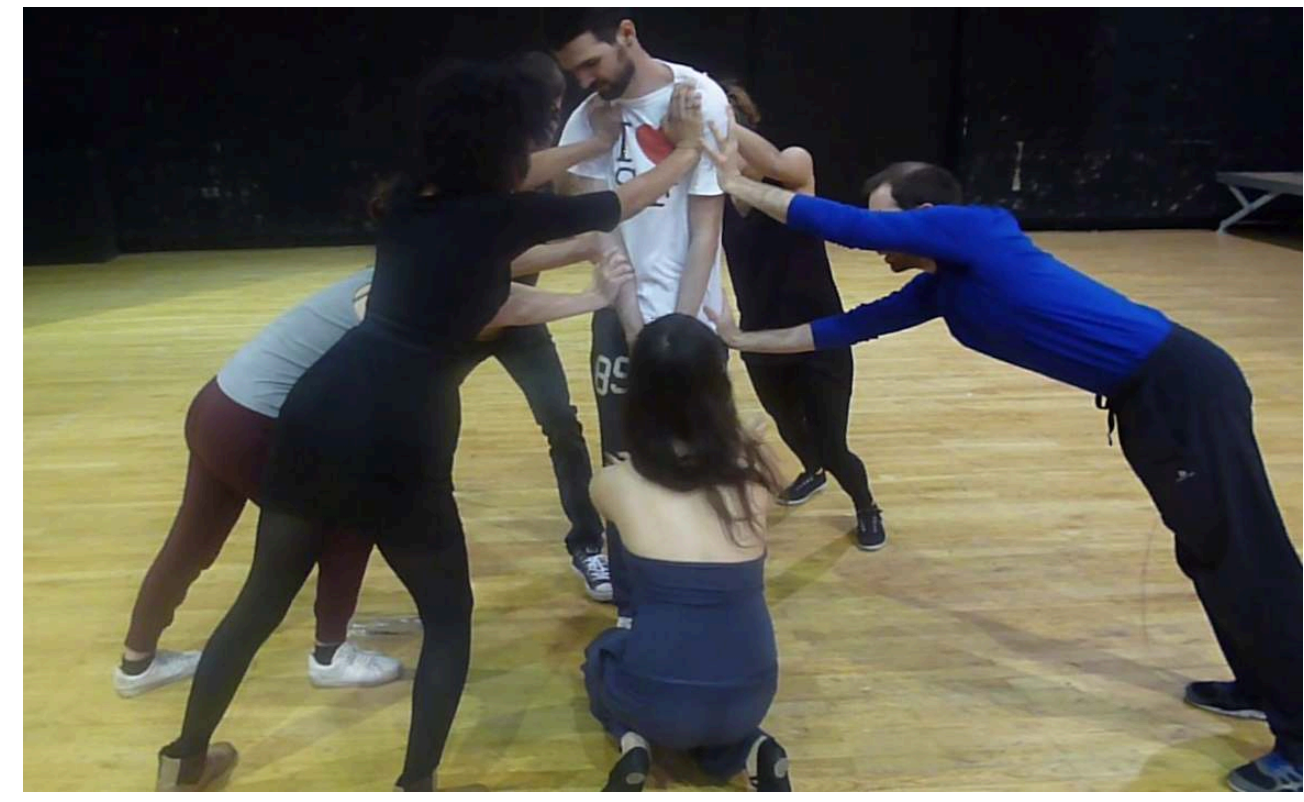

69 Using forces and counterforces to create a balanced structure 


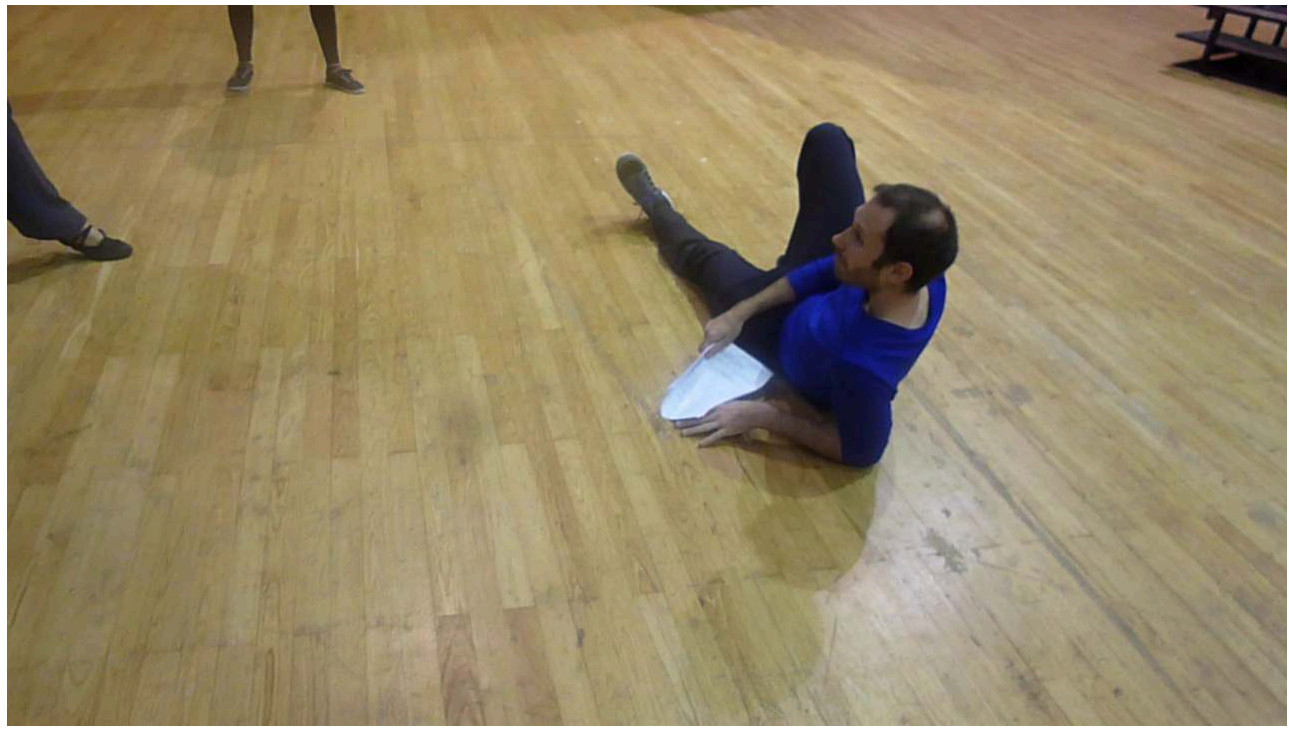

Delivering 'How do you do Lady Windermere? ' beach style

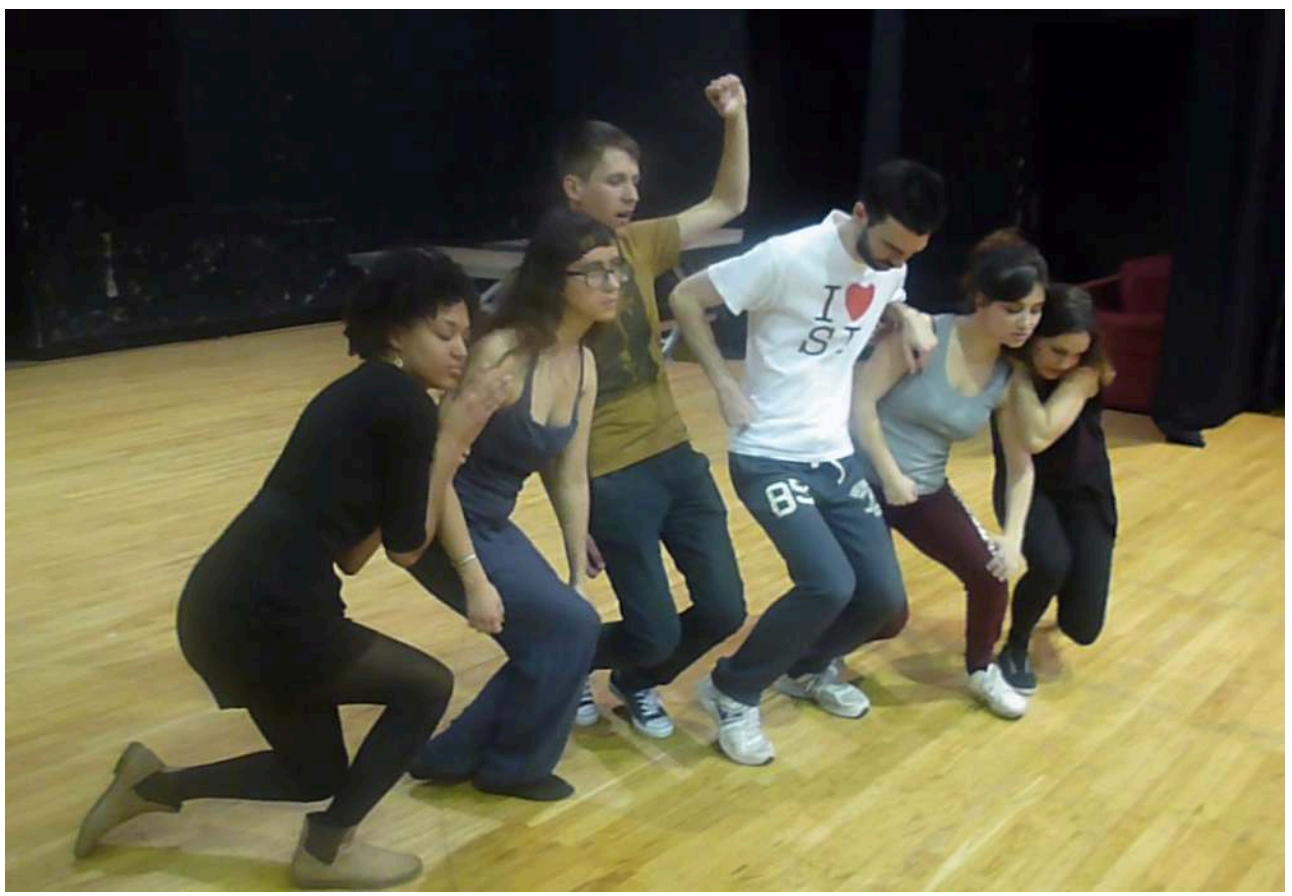

Group melts to the ground 


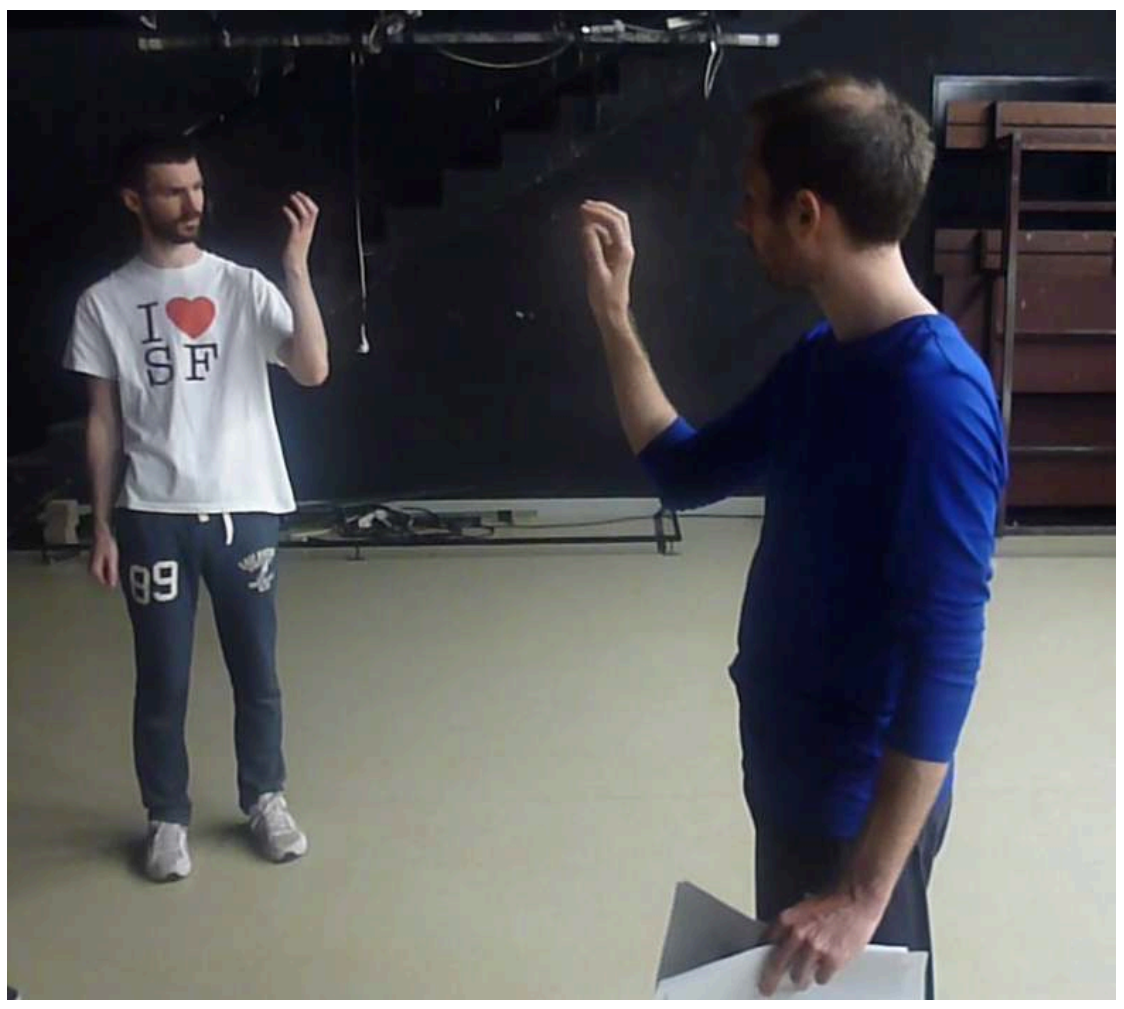

72 'Ignorance is like a delicate exotic fruit'

Asher, James. Children's First Language as a Model for Second Language Learning. The Modern Language Journal, vol. 56, No. 3 (Mar., 1972), 133-139.

Birdwhistell, Ray. Kinesics and Context. Essays on Body Motion Communication. Philadelphia: University of Pennsylvania Press, 1970.

Brown, Penelope and Levinson, Stephen. Politeness : some universals in language use. Cambridge : Cambridge University Press, 1987.

Culpeper, Jonathan. Impoliteness : Using Language to Cause Offence. Cambridge : Cambridge University Press, 2011.

Ekman, Paul. Emotions Revealed. Recognizing Faces and Feelings to Improve Communication and Emotional Life. New Yor : Times Books, 2003.

Frey, Siegfried. Tonic aspects of behavior in interaction. In A. Kendon, R. Harris, M. Richie Key (Eds.), Organization of Face-to-Face Behavior. The Hague : Mouton, 1975 Goffman, Erving. The Presentation of Self in Everyday Life. New York : Anchor Books, 1959. Goffman, Erving. Interaction Ritual. Essays on Face-to-Face Behavior. New York : Pantheon Books, 1967.

Goffman, Erving. The Interaction Order. Presidential address delivered at the Annual Meeting of the American Sociological Association in San Francisco. Published in The American Sociological Review (ASR), Feb. 1983, Vol 48 N 1, 1-17, 1982.

Lapaire, Jean-Rémi, Magnard Jean, and Blanc, Mélissa. "Langues vivantes en vie". Plenary lecture-performance given at the RANACLES 2013 conference, Bordeaux, 30.11.2013.

URL : https://www.youtube.com/watch ?v =takomU73y3k

Lapaire, Jean-Rémi, Magnard Jean, and Blanc, Mélissa. "Living speech or the bodily life of language." SKASE Journal of Theoretical Linguistics, Volume 12 - 2015, N³, 528-541.

URL: http://www.skase.sk/Volumes/JTL29/pdf_doc/23.pdf 
Lapaire, Jean-Rémi, Magnard Jean, and Blanc, Mélissa. “Chorégraphies de la parole”, Miranda, 11 | 2015. URL: http://miranda.revues.org/7548

Langacker, Ronald. Cognitive Grammar. New York, NY. : Oxford University Press, 2008. Schechner, Richard. Performance Theory. London : Routledge, 2003.

Whorf, Benjamin Lee. Language, Thought and Reality. Cambridge, Mass. : The MIT Press, 1956.

Wilde, Oscar. Lady Windermere's Fan. Project Gutenberg, e-book 790. Transcribed from the 1917 Methuen \& Co. Ltd Edition by David Price, 1997 (1893).

Wilde, Oscar. The Importance of Being Earnest. A Trivial Comedy for Serious People. Project Gutenberg, e-book 844. Transcribed by David Price, 1997 (1895a).

Wilde, Oscar. An Ideal Husband. Project Gutenberg, e-book 885. Transcribed from the 1912 Methuen \& Co. Ltd Edition by David Price, 2009 (1895b).

\section{NOTES}

1. Jean Magnard is a professional dancer / choreographer based in Bordeaux, France. He has coauthored a number of written and staged pieces with Mélissa Blanc and Jean-Rémi Lapaire (2014, 2015).

2. At the time of the performance, all six were graduate students in English studies, enrolled in the Master of Arts program, Year 1, «Language, Body and Mind» module, Université Bordeaux Montaigne, France.

3. Each 'parade' is performed 3 times in close succession, using different expressive styles, with corresponding gestural, postural and intonational modes: 'regular', 'at a distance', 'beach style'.

4. The dialogues, puns and witty remarks are all taken from Wilde (1893, 1895a, 1895b).

5. Adapted from Goffman (1967). As the girls part, one grins and the other pouts.

6. Adapted from Asher (1974).

7. Adapted from Asher (1974).

\section{INDEX}

Subjects: Dance

Mots-clés: cognition sociale incarnée, dramaturgie de la parole, chorégraphie de la parole, pragmatique, rituels sociaux, acteurs sociaux, social interaction

Keywords: embodied social cognition, dramaturgical model of speech, choreography of speech, pragmatics, social ritual, social actors, interaction sociale 
AUTHORS

JEAN -RÉMI LAPAIRE

Professeur

Université Bordeaux Montaigne

jrlapaire@u-bordeaux-montaigne.fr 